\title{
BIOFACIES AND TAPHOFACIES OF A HOLOCENE MACROTIDAL ENVIRONMENT: BAHIA LA CHOLLA, NORTHERN GULF OF CALIFORNIA
}

\section{BIOFACIES Y TAFOFACIES DE UN AMBIENTE MACROMAREAL DEL HOLOCENO: BAHIA LA CHOLLA, NORTE DEL GOLFO DE CALIFORNIA}

\author{
Keith H. Meldahl \\ Department of Geology \\ Oberlin College \\ Oberlin, Ohio 44074 \\ USA
}

Recibido en mayo de 1994; aceptado en noviembre de 1994

\begin{abstract}
Recognition of the paleoenvironmental significance of biofacies and taphofacies in the fossil record is greatly aided by their study in modern sedimentary environments. Holocene molluscan shell assemblages of Bahía la Cholla, a macrotidal shallow marine environment in the northern Gulf of California, form distinct biofacies and taphofacies whose distribution is controlled by different environmental variables.

Biofacies primarily reflect variation in substrate. Distinctive molluscan communities characterize: 1) Salt marsh and innermost tidal flats: organic-rich fine sediments, dominated by epifaunal deposit feeders and deep infaunal suspension feeders; 2) Inner, middle and outer tidal flats: fine to coarse sand, dominated by shallow infaunal suspension feeders; 3) Tidal channel and rocky intertidal zone: hard substrates of shells or rock, dominated by epifaunal algal grazers; 4) Rocky subtidal zone: alternating rock and sand, dominated by attached epifaunal suspension feeders and shallow infaunal suspension feeders.

Taphofacies, based on taphonomy of the shallow infaunal bivalve Chione spp., primarily reflect variation in tidal submergence time and current energy. Distinctive suites of taphonomic attributes characterize: 1) Outer tidal flats, rocky intertidal zone, and rocky subtidal zone: environments experiencing prolonged or continuous tidal submergence and high tidal current velocities, characterized by high levels of abrasion, bioerosion by bivalves and clionid sponges, and encrustation by bryozoans; 2) Tidal channel: an environment experiencing continuous submergence and the strongest tidal currents, characterized by very high levels of abrasion, bioerosion by algae, and encrustation by serpulid polychaetes; 3) Salt marsh, inner tidal flats and middle tidal flats: environments experiencing relatively short periods of submergence and low tidal current velocities, characterized by low levels of taphonomic alteration.

Biofacies and taphofacies provide different and complementary types of information about the sedimentary environments of Bahia la Cholla. In paleoecological studies, a more complete picture of ancient environments can be generated by integrating taphonomic data with taxonomic and ecologic data.
\end{abstract}

Key words: taphonomy, intertidal, biofacies, taphofacies, paleoenvironmental interpretation. 


\section{RESUMEN}

El reconocimiento del significado paleoambiental de las facies y biofacies de los registros fósiles se facilita en gran medida al estudiarse en ambientes sedimentarios modernos. Los conjuntos de conchas de moluscos del holoceno de bahía La Cholla, un ambiente marino somero macromareal del norte del golfo de California, forman distintas biofacies y tafofacies, cuya distribución es controlada por diferentes variables ambientales.

Las biofacies reflejan principalmente variación en el sustrato. Las diferentes comunidades de moluscos caracterizan: 1) la marisma y las planicies intermareales: con sedimentos finos y ricos en materia orgánica, dominados por epifauna sedimentivora e infauna profunda suspensívora; 2) las planicies intermareales interna, media y externa: con arena de fina a gruesa, dominada por infauna somera suspensívora; 3) el canal de marea y la zona rocosa intermareal: con sustratos duros de concha o roca, dominados por epifauna pacedora de algas; 4) la zona rocosa submareal: con arena y roca alternadas, dominada por epifauna sésil suspensívora e infauna somera suspensívora.

Las tafofacies basadas en la tafonomia del bivalvo infáunico somero Chione spp. reflejan variaciones principalmente en tiempo de sumersión mareal y energía de corriente. Los distintos conjuntos de atributos tafonómicos caracterizan: 1) las planicies intermareales externas y las zonas rocosas intermareal y submareal: con ambientes que experimentan sumersión mareal continua o prolongada y velocidades altas de corriente de marea, caracterizados por niveles altos de abrasión, bioerosión por bivalvos y esponjas perforadoras, e incrustación por briozoarios; 2) el canal de marea: con un ambiente que experimenta sumersión continua y las corrientes de marea más fuertes, caracterizado por niveles muy altos de abrasión, bioerosión por algas e incrustación por poliquetos serpúlidos; 3) la marisma y las planicies mareales internas y medias: con ambientes que experimentan periodos de sumersión relativamente cortos y velocidades de corriente de marea bajas, caracterizados por niveles bajos de alteración tafonómica.

Las biofacies y tafofacies proporcionan tipos de información diferentes y complementarios sobre los ambientes sedimentarios de bahí La Cholla. En los estudios paleoecológicos, se logra una imagen más completa de los ambientes antiguos integrando datos tafonómicos con datos taxonómicos y ecológicos.

Palabras clave: tafonomia, intermareal, biofacies, tafofacies, interpretación paleoambiental.

\section{INTRODUCTION}

Accurate reconstruction of ancient sedimentary environments using fossils is a major goal of paleoecology. Fossil assemblages reflect their ambient sedimentary environment in two major ways: through ecology, the interaction of once living individuals and communities with their environment, and through taphonomy, the interaction of dead organic remains with their environment.

The paleoenvironmental significance of taphonomy has received much attention in recent years (e.g., Brett and Baird, 1986; Kidwell, 1991; Kidwell and Boscence, 1991; Parsons and Brett, 1991; Meldahl, 1993). Determination of ecologic and taphonomic "fingerprints" remaining on skeletal remains in modern sedimentary environments aids greatly in

\section{INTRODUCCION}

La reconstrucción precisa de ambientes sedimentarios antiguos usando fósiles es una de las metas principales de la paleoecología. Los conjuntos de fósiles reflejan su ambiente sedimentario de dos formas principales: a través de la ecologia, la interacción de los individuos y comunidades en otro tiempo vivos con su ambiente, y a través de la tafonomía, la interacción de los restos orgánicos muertos con su ambiente.

El significado paleoambiental de la tafonomia ha cobrado interés en años recientes (e.g., Brett y Baird, 1986; Kidwell, 1991; Kidwell y Boscence, 1991; Parsons y Brett, 1991; Meldahl, 1993). La determinación de las "huellas digitales" ecológicas y tafonómicas que quedan sobre los restos esqueléticos en 
interpreting the significance of these features in ancient sedimentary environments (e.g., Parsons, 1989; Davies et al., 1989, 1990; Meldah1 and Flessa, 1990; Greenstein, 1991). This study demonstrates how biofacies, based on variation in molluscan species composition, trophic groups, and life habit groups, and taphofacies, based on variation in molluscan taphonomy, provide different and complementary types of information about sedimentary environments and processes in a macrotidal shallow marine bay.

\section{STUDY AREA}

The study was conducted in the intertidal and shallow subtidal environments of Bahía la Cholla, northern Gulf of California, Sonora, Mexico ( $31^{\circ} 20^{\prime} \mathrm{N}, 113^{\circ} 37^{\prime} \mathrm{W}$; Fig. 1). The bay occurs approximately $10 \mathrm{~km}$ northwest along the coast from the town of Puerto Peñasco. The diverse fauna and extensive array of sedimentary environments have made Bahía la Cholla an excellent natural laboratory for paleoecologic studies (e.g., Fürsich and Flessa, 1987; Meldahl, 1987, 1990; Stearley and Ekdale, 1989; Aberhan and Fürsich, 1991; Feige and Fürsich, 1991; Cutler, 1991; Flessa et al., 1993). Comprehensive analyses of the sedimentology, molluscan ecology and taphonomy of Bahía la Cholla are presented in edited volumes by Flessa (1987) and Fürsich and Flessa (1991).

Bahía la Cholla experiences mixed semidiurnal tides that commonly exceed $7 \mathrm{~m}$ spring range (Thompson. 1993). The high tidal range coupled with the gentle gradient of the coast expose nearly $10 \mathrm{~km}^{2}$ of intertidal environments (Fig. 1). Eight distinct sedimentary environments are recognized in this study. These are similar to those recognized by Fürsich and Flessa (1991) on the basis of topography, sediment grain size and vegetation. The environments are shown in Fig. 1. and their major features are summarized in table 1 .

The area supports an abundant and diverse fauna belonging to the Panamic Province. Two hundred eighteen species of molluscs ( $127 \mathrm{bi}$ valves, 88 gastropods, 3 scaphopods) have been identified from the intertidal zone (Fürsich et al., 1991). Also present are sponges, tunicates, ambientes sedimentarios modernos ayuda en gran medida a interpretar el significado de estas características en ambientes sedimentarios antiguos (e.g., Parsons, 1989; Davies et al., 1989, 1990; Meldahl y Flessa, 1990; Greenstein, 1991). Este estudio demuestra cómo las biofacies, basadas en las variaciones de composición de las especies de moluscos, grupos tróficos y grupos de hábitos de vida, y las tafofacies, basadas en la variación de la tatonomía de los moluscos, proveen tipos de información diferentes y complementarios sobre ambientes sedimentarios y procesos en una bahía macromareal somera.

\section{AREA DE ESTUDIO}

El estudio se realizó en los ambientes intermareal y submareal somero de bahía La Cholla, en el norte del golfo de California, Sonora, México ( $31^{\circ} 20^{\prime} \mathrm{N}, 113^{\circ} 37^{\prime} \mathrm{O}$; Fig. 1). La bahía está aproximadamente $10 \mathrm{~km}$ al noroeste del poblado de Puerto Peñasco. La fauna diversa y la extensa varicdad de ambientes sedimentarios han hecho de esta bahía un excelente laboratorio natural para estudios paleoecológicos (e.g., Fürsich y Flessa, 1987; Meldahl, 1987, 1990; Stearley y Ekdale, 1989; Aberhan y Fürsich, 1991; Feige y Fürsich, 1991; Cutler, 1991; Flessa et al., 1993). Análisis comprensivos de sedimentología, así como de ecología y tafonomía de moluscos de bahía La Cholla se encuentran en los volúmenes editados por Flessa (1987) y Fürsich y Flessa (1991).

Bahía La Cholla tiene mareas semidiurnas mixtas que comúnmente exceden $7 \mathrm{~m}$ de intervalo (Thompson, 1993). El alto intervalo de marea junto con el suave gradiente de la costa dejan expuestos cerca de $10 \mathrm{~km}^{2}$ de ambientes intermareales (Fig. 1). En este estudio, se reconocen ocho ambientes sedimentarios diferentes. Estos son similares a los reconocidos por Fürsich y Flessa (1991), con base en la topografía, el tamaño de grano del sedimento y la vegetación. Los ambientes se muestran en la Fig. 1 y sus caracerísticas se resumen en la tabla 1.

El área soporta una fauna abundante y diversa, perteneciente a la provincia panámica. En la zona intermareal, se han identificado 218 

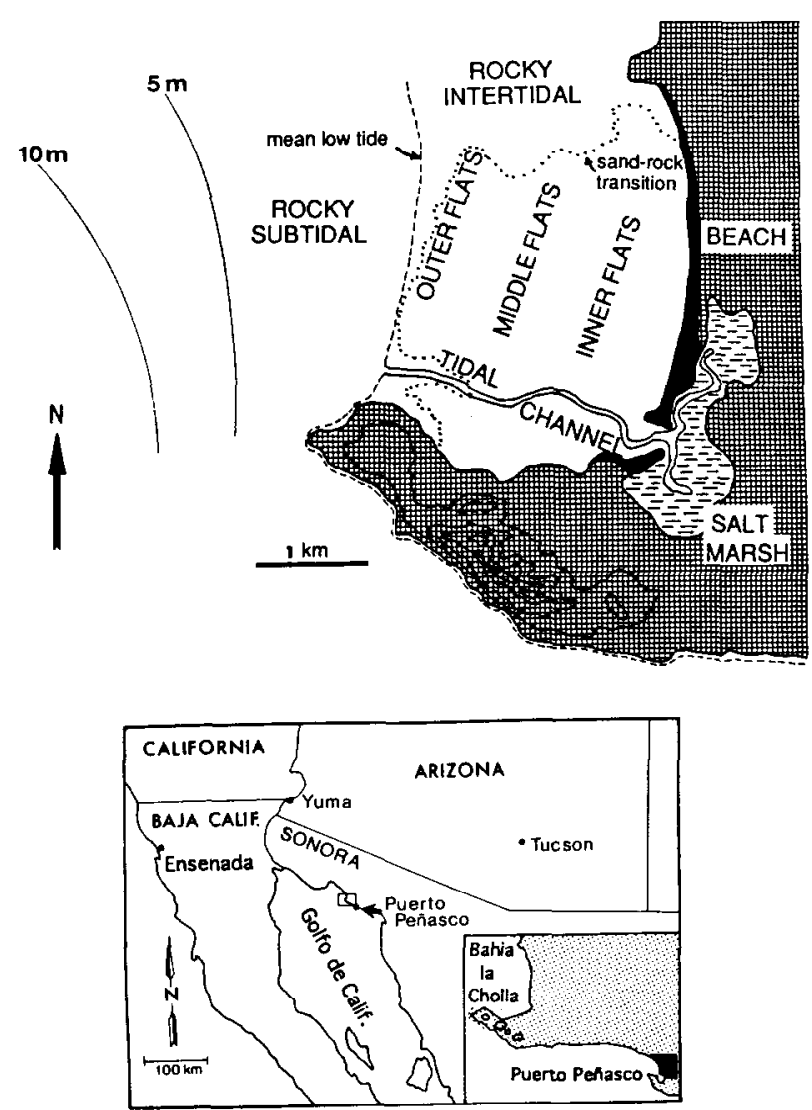

Figure 1. Bahía la Cholla sedimentary environments (table 1). Contours (solid lines) indicate depth in meters below mean low tide (dashed line). Dotted line indicates transition from sand-dominated tidal flats (south and east of line) to rock-dominated intertidal and subtidal environments (north and west of line).

Figura 1. Ambientes sedimentarios de bahía La Cholla (tabla 1). Los contornos (líneas continuas) indican profundidad abajo de la marea baja media (línea discontinua), en metros. La línea punteada indica la transición de planicies mareales dominadas por arena (al sur y al este de la línea) a ambientes intermareales y submareales dominados por rocas (al norte y oeste de la línea).

crustaceans, echinoids, cnidarians, numerous polychaetes and rare inarticulate brachiopods. Dead mollusc shells are commonly exploited as substrates by bioeroding and encrusting organisms. Bioeroders include algae, clionid sponges, bivalves, bryozoans and spionid polychaetes. Encrusters include serpulid polychaetes, bryozoans, barnacles, vermetid gastropods, brown algae, calcareous algae, corals, oysters, sponges and foraminifera. Feige and Fürsich (1991) pro- especies de moluscos (127 bivalvos, 88 gastrópodos y 3 escafópodos; Fürsich et al., 1991). Están presentes además esponjas, tunicados, crustáceos, equinodermos, cnidarios, numerosos poliquetos $y$, con menor frecuencia, branquiópodos inarticulados. Las conchas de moluscos muertos son aprovechadas comúnmente como sustrato por organismos bioerosionadores e incrustantes. Entre los bioerosionadores se encuentran algas, esponjas cliónidas, 
Table 1. Sedimentary Environments of Bahía la Cholla.

Salt marsh

Inner tidal flats

Middle tidal flats

Outer tidal flats

Rocky intertidal zone

Rocky subtidal zone
Sediments mostly poorly sorted organic-rich mud, silt and fine sand. Dense beds of the halophytes Salicornia sp., Sueda sp. and Distichlis sp. contain the semi-infaunal byssate bivalve Mytella guyanensis. Crabs (Uca sp., Eurytium sp.) excavate extensive burrow networks. Deposit-feeding gastropod Cerithidea sp. is abundant, and bivalves Chione fluctifraga and Tagelus sp. are common. Marsh dissected by anastomosing tidal channels floored by coarse sand and shell gravel.

Sediments mostly fine sand and silt. Large-scale bedforms absent, though small wave ripples common. The upper $1.2 \mathrm{~cm}$ of sediment commonly bound by algae, providing cohesiveness and causing surface to erode into distinctive mesa-like topography. Deep-burrowing shrimp Callianassa sp. and Upogebia sp. are very abundant in some areas. Shell abundance low in surface sediments. Common molluscs include Cerithidea sp., Tagelus sp. C. fluctifraga, Nassarius sp. and Cryptomya californica (a bivalve living in the walls of callianassid shrimp burrows).

Transitional zone between inner and outer tidal flats, characterized by larger wave ripples, some current ripples, fine to medium sand, low to absent silt content, and absence of mesa-like topography due to lower organic content of surface sediments. Feeding pits dug by sting rays are common. Shallow burrowing bivalves Lucina lampra, Felaniella sericata, Parvilucina mazatlanica and $C$. californiensis are common.

Sediments mostly fine to coarse grained sand with abundant shells and shell fragments. Large wave and current ripples abundant. Topography dominated by north-south oriented, long-wavelength, low-amplitude sand waves. Troughs of sand waves commonly contain a dense shell lag. Bivalves L. lampra, F. sericata, $P$. mazatlanica, and $C$. californiensis are common. Bivalves Megapitaria squalida, Trachycardium spp. and Dosinia spp., and gastropods Agaronia testacea, Olivella dama, Oliva spp. and Polinices uber occur in lower abundance.

Dominates north side of bay (Fig. 1). Consists of low flat outcrops of weakly cemented, highly porous Pleistocene coquina, exposed intermittently across the northern side of the bay and in the lowest intertidal and subtidal zones on the western side of the bay. Irregularity of coquina surface results in alternating rock outcrops with patches of shallow sand. Supports numerous hard-substrate taxa, including sponges, barnacles, colonial tunicates, algae and molluscs. Grazing gastropod Cerithium stercusmuscarum very abundant. Common in the lower rocky intertidal zone are byssate epifaunal bivalves Cardita affinis, Arca pacifi$c a$ and Modiolus capax, and epifaunal gastropod Crepidula spp. Patches of shallow sand among rock outcrops support common $C$. californiensis

Subtidal region to $10 \mathrm{~m}$ below mean low water level consists of low outcrops of Pleistocene coquina alternating with large patches of fine to coarse grained sand. This environment supports the highest diversity at Bahia la Cholla. Common hard substrate taxa include Pteria sterna, M. capax, A. pacifica, C. affinis, and Lithophaga spp. (boring into the coquina substrate). Sand patches between rocky outcrops support abundant $C$. californiensis and common Laevicardium spp., Trachycardium spp., Tellina spp. and $M$ squalida. 
Table 1 (Cont.)

\begin{tabular}{|c|c|}
\hline Beach & $\begin{array}{l}\text { Divides the inner tidal flats from the salt marsh (Fig. 1). Sediments mostly me- } \\
\text { dium to coarse grained sand and molluscan bioclasts. Coarse material concen- } \\
\text { trated in linear bands along the beach face, corresponding to zones of } \\
\text { concentrated wave energy during tidal cycles. Beach shells are derived from a } \\
\text { variety of intertidal environments, but majority originate in rocky intertidal zone } \\
\text { on north side of the bay, transported southward along beach by longshore drift. }\end{array}$ \\
\hline Tidal channel & $\begin{array}{l}\text { Flows from salt marsh to subtidal zone; is broad and shallow where it cuts } \\
\text { across the tidal flats, but narrow and deep where it enters the salt marsh. Chan- } \\
\text { nel floor is continuously submerged even at low tide. Sediments mostly poorly } \\
\text { sorted sand and shell-gravel. Large sand waves, planar bedded sands, current } \\
\text { lineations and common current-oriented shells indicate high flow regimes. Com- } \\
\text { mon are shallow infaunal bivalves Protothaca grata and C. fluctifraga, and gas- } \\
\text { tropods } C \text {. stercusmuscarum and Theodoxus luteofasciatus grazing on algae- } \\
\text { coated shells. }\end{array}$ \\
\hline
\end{tabular}

Tabla 1. Ambientes sedimentarios de bahía La Cholla.

En general, sedimentos pobremente clasificados, lodo rico en materia orgánica,
limo y arena fina. Lechos densos de las halófitas Salicornia sp., Sueda sp. y Dis-
tichlis sp. contienen el bivalvo bisado seminfáunico Mytella guyanensis. Los
cangrejos cavan amplias redes de excavaciones. El gastrópodo detritófago Cere-
thidea sp. es abundante y los bivalvos Chione fluctifraga y Tagelus sp. son co-
munes. Marisma disectada por canales de marea anastónicos con suelos de arena
gruesa y grava de conchas.

Planicies mareales Sedimentos mayormente de arena fina y limo. No hay formas de lechos a gran esinternas cala, aunque son comunes las pequeñas ondas de olas. La parte superior del sedimento, 1 a $2 \mathrm{~cm}$, está unida con frecuencia por algas que le dan cohesión y causan que la superficie se erosione con topografia de tipo mesa. Camarones que excavan profundamente, Callianassa sp. y Upogebia sp. son muy abundantes en algunas áreas. La abundancia de conchas es baja en los sedimentos de la superficie. Los moluscos comunes son Cerithidea sp., Tagelus sp., C. fluctifraga, Nassarius sp. y Cryptomya californica (un bivalvo que habita los muros de las madrigueras del camarón calianásido).

Planicies mareales Zona de transición entre planicies mareales internas y externas, caracterizada por medias ondulaciones de olas más grandes, algunas ondulaciones de corriente, arena de grano fino a grano mediano, contenido de limo de bajo a ausente, y ausencia de topografia de tipo mesa, debido a un contenido orgánico más bajo en los sedimentos de la superficie. Son comunes los hoyos de alimentación excavados por rayas. Bivalvos excavadores poco profundos, Lucina lampra, Felaniella sericata. Parvilucina mazatlanica y Chione californiensis son comunes.

Planicies mareales Sedimentos mayormente de arena de grano fino a grueso con abundantes conexternas chas y fragmentos de conchas. Olas grandes y ondulaciones de corriente abundantes. La topografia está dominada por olas de arena de periodo largo, de amplitud baja, con orientación norte-sur. Surcos de olas de arena con frecuencia 
Tabla 1 (Cont.)

contienen un denso rezago de conchas . Los bivalvos L. lampra, $F$. sericata, $P$. mazatlanica y $C$. californiensis son comunes. Los bivalvos Megapitaria squalida, Trachycardium spp. y Dosinia spp., y los gastrópodos Agaronia testacea, Olivella dama, Oliva spp. y Polinices uber son menos abundantes.

Zona intermareal Domina el lado norte de la bahía (Fig. 1). Consiste en afloramientos bajos y plarocosa nos de coquina del pleistoceno débilmente cementada y altamente porosa, descubierta a intervalos a través del lado norte de la bahía y en las zonas intermareal y submareal más bajas del lado oeste de la bahía. De la irregularidad de la superficie de coquina resultan afloramientos rocosos alternados con manchas de arena poco profunda. Sostiene numerosos organismos de sustrato duro, incluyendo esponjas, balanos, tunicados coloniales, algas y moluscos. El gastrópodo pacedor Cerithium stercusmuscarum es muy abundante. En las zonas intermareales rocosas bajas son comunes los bivalvos bisados epifáunicos Cardita affinis, A. pacifica y $M$. capax, y el gastrópodo epifáunico Crepidula spp. Manchas de arena poco profundas entre afloramientos rocosos sostienen $C$. californiensis común.

Zona submareal Region submareal hasta $10 \mathrm{~m}$ debajo del nivel bajo promedio del agua. Consiste rocosa en afloramientos bajos de coquina del pleistoceno alternados con manchas grandes de arena de grano fino a grano grueso. Este ambiente mantiene la mayor diversidad de bahía la Cholla. Son comunes las especies de sustrato duro Pteria sterna, $M$. capax, A. pacifica, C. affinis y Lithophaga spp. (que perforan el sustrato de coquina). Las manchas de arena entre afloramientos rocosos sostienen abundancia de $C$. californiensis y Laevicardium spp. común, Trachycardium spp., Tellina spp. y M. squalida.

Playa Separa los planos mareales interiores de la marisma (fig. 1). Sedimentos mayormente de arena de grano mediano a grueso y bioclastos de moluscos. El material grueso se concentra en bandas lineales a lo largo de la cara de la playa, y corresponde a zonas de energía de las olas concentrada durante ciclos mareales. Las conchas de la playa se derivan de una variedad de ambientes intermareales, pero la mayoría se originan en la zona intermareal rocosa del lado norte de la bahía y son transportadas hacia el sur a lo largo de la playa por la corriente costera.

Canal mareal Fluye de la marisma a la zona submareal; es ancho y poco profundo donde atraviesa los planos mareales pero angosto y profundo donde entra a la marisma . El suelo del canal está sumergido continuamente aun durante la marea baja. Los sedimentos son mayormente de arena y grava de conchas pobremente clasificadas. Grandes olas de arena, asentamientos de arena planos, trazos de corriente y conchas orientados hacia la corriente indican regimenes de flujo alto. Son comunes los bivalvos infáunicos poco profundos Protothaca grata y C. fluctifraga, y los gasterópodos C. stercusmuscarum y Theodoxus luteofasciatus, pacedores de algas adheridas a las conchas. 
vide a detailed analysis of shell bioerosion and encrustation at Bahía la Cholla.

Sediments in the area are dominantly fine to coarse grained terrigenous sand and bioclastic particles (shell fragments and shells). Silt occurs in the inner flats, and mud deposition is limited to the upper areas of the salt marsh. Sediments are generally moderately to very poorly sorted, due to the abundance of bioclastic particles. Bioclastic content of the sediment ranges from 0 to more than $50 \%$.

Radiocarbon dates on Holocene shells demonstrate extremely low sedimentation rates and extensive time-averaging of molluscan taphocoenoses at Bahía la Cholla. Flessa et al. (1993) age-dated disarticulated valves of Chione spp. from the floor of the tidal channel and surface of the inner tidal flats. The median calendar age for 13 dated tidal channel valves was 427 y.b.p., with a maximum age of 1,752 y.b.p. The median calendar age for 17 dated inner tidal flat valves was 483 y.b.p., with a maximum age of 3,569 y.b.p. Net sedimentation rates are so low that shells apparently remain in the surface mixing zone (the "taphonomically active zone" of Davies et al. [1989]) for hundreds to thousands of years. The ability of shells to persist such an extensive period in this macrotidal environment is attributed by Flessa et al. (1993) to frequent shallow burial of shells, which slows down the rates of destructive taphonomic processes. Frequent shallow burial results from both physical and biogenic sediment reworking.

Low flat outcrops of lithified Pleistocene coquina are exposed extensively in the area, particularly in the intertidal region on the north side of the bay, and in the subtidal zone. Figure 1 shows the distribution of coquina exposures. This coquina has been correlated by Ortlieb (1991) with the Sangamon interglacial highstand (oxygen-isotope stage 5e; 125,000 y.b.p.), when sea level stood approximately $6 \mathrm{~m}$ higher than present. The coquina is similar in texture, grain size and faunal composition to the modern lower intertidal and shallow subtidal environments of the bay (Fürsich and Flessa, 1987; Aberhan and Fürsich, 1991). Coquina outcrops provide a hard substrate for numerous epifauna. These outcrops form the rocky intertidal and rocky subtidal environments shown in Fig. 1. bivalvos, briozoarios y poliquetos espiónidos. Entre los incrustantes se encuentran serpúlidos, poliquetos, briozoarios, balanos, gastrópodos vermétidos, algas pardas, algas calcáreas, corales, ostras, esponjas y foraminíferos. Feige y Fürsich (1991) proporcionan un análisis detallado de la bioerosión e incrustación de conchas en la bahía La Cholla.

Los sedimentos de esta área son principalmente arena terrígena de grano fino a grueso y partículas bioclásticas (conchas y fragmentos de conchas). Se encuentra limo en las planicies internas y el depósito de lodo se limita a las áreas más altas de la marisma. En general, los sedimentos están clasificados de moderados a muy pobres, debido a la abundancia de partículas bioclásticas. El contenido bioclástico de los sedimentos varía de 0 a más de $50 \%$.

Las fechas de radiocarbón de las conchas del holoceno demuestran tasas de sedimentación extremadamente bajas y extensos tiempos de vida media en la tafocenosis de moluscos en bahía La Cholla. Flessa et al. (1993) midieron la edad de las valvas desarticuladas de Chione spp. del suelo del canal de marea y de la superficie de las planicies mareales internas. La edad media calendárica para 13 valvas del canal de marea fue 427 años, con edad máxima de 1,752 años. La edad calendárica media para 17 valvas de la planicie mareal interna fue 483 años, con edad máxima de 3,569 años. Las tasas netas de sedimentación son tan bajas que las conchas aparentemente quedan en la zona de mezclado de la superficie (la "zona tafonómicamente activa" de Davies et al. [1989]) durante cientos a miles de años. El que las conchas puedan persistir de cientos a miles de años en este ambiente macromareal es atribuido por Flessa $e t$ al. (1993) al enterramiento somero frecuente de las conchas, que disminuye las tasas de los procesos tafonómicos destructivos. El enterramiento somero frecuente es resultado del retrabajo tanto físico como biogénico de los sedimentos.

Los afloramientos bajos y planos de coquina litificada del pleistoceno están extensamente expuestos en el área, particularmente en la región intermareal del lado norte de la bahía y en la zona submareal. La Fig. 1 muestra la distribución de las coquinas expuestas. Ortlieb (1991) relacionó esta coquina con el periodo in- 
Table 2. Taphonomic data from Bahía la Cholla .

Valves of the shallow infaunal bivalves Chione californiensis and/or C. fluctifraga were coded on a presence/absence basis for the following taphonomic attributes. Supplemental valves were collected at stations where abundance in original samples was low. Taxonomic identification of bioeroding organisms, ichnotaxa, and encrusting organisms from Feige and Fürsich (1991).

\section{Percentage of valves fragmented. Fragment defined as $>10 \%$ of original valve missing. \\ 2. Percentage of whole articulated valves. \\ 3. Percentage of abraded whole disarticu- lated valves. Abrasion defined as rounding of valves edges and reduction of ornament on the exterior of valves, identifiable without magnification.}

4. Percentage of bioeroded whole disarticulated valves. Bioerosion defined by presence of bioeroding organisms on either interior or exterior of valves, recognizable with $10 \mathrm{x}$ magnification.

Categories of bioerosion

a) endolithic algae (taxonomy uncertain)

b) clionid sponges (Cliona spp., create the ichnogenus Entobia)

c) spionid polychaetes (Polydora spp., create the ichnogenera Caulostrepsis, Maeandropolydora, and Helicotaphrichnus) d) endolithic bivalves (Gastrochaena truncata and G. ovata, create the ichnogenus Gastrochaenolites)

\section{METHODS}

Fifty-eight samples of mollusc shells were collected at roughly evenly-spaced sites in the study area. Sites were located on a base map by triangulation. There were 49 intertidal sites and 9 subtidal sites (up to $10 \mathrm{~m}$ below mean low tide). Samples were collected by digging up the upper $5 \mathrm{~cm}$ of sediment and sieving it through a $6 \mathrm{~mm}$ mesh screen, collecting dead shells until a 3.8 I sample bag was full, shell abundance permitting. Subtidal samples were collected using snorkel and SCUBA

The 58 samples contained a total of 12,690 individuals belonging to 85 identifiable mollusc species. Species were identified using Beckvar et al. (1987) and Keen (1971). Species were classified into the following trophic groups:

\section{Percentage of encrusted whole disarticul-} ated valves. Encrustation defined by presence of encrusting organisms on either interior or exterior of whole valves, recognizable without magnification.

Categories of encrustation

a) serpulid polychaetes (common taxa are Pomatostegus cf. polytrema, Serpula cf. concharum, Pomatoceras cf. triqueter, and Spirorbis $\mathrm{cf}$. variabilis)

b) vermetid gastropods (Vermetus indentatus, Tripsycha tripsycha, and Serpulorbis margaritaceus)

c) bryozoans

d) balanids

e) brown algae

f) calcareous algae

g) foraminifera

h) bivalves (oysters)

i) cnidarians (corals)

j) sponges. terglacial superior de Sangamon (etapa $5 \mathrm{e}$ de isótopo-oxígeno; 125,000 años), cuando el nivel dcl mar cstaba aproximadamente $6 \mathrm{~m}$ más arriba del nivel actual. La coquina es semejante en textura, tamaño de grano y composición fáunistica a los ambientes modernos intermareal inferior y submareal somero de la bahía (Fürsich y Flessa, 1987; Aberhan y Fürsich, 1991). Los afloramientos de coquina proporcionan un sustrato duro para numerosa epifauna. Estos afloramientos forman los ambientes intermareal rocoso y submareal rocoso que se muestran en la Fig. 1 .

\section{METODOS}

Se recolectaron 58 muestras de conchas de moluscos de sitios espaciados con relativa uniformidad en el área de estudio. Los sitios se 
Tabla 2. Datos tafonómicos de bahía La Cholla.

Las valvas de los bivalvos infáunicos someros Chione californiensis y/o C. fluctifraga se codificaron con base en la presencia o ausencia de los atributos tafonómicos siguientes. Se recolectaron valvas suplementarias en las estaciones donde la abundacia de muestras originales fue baja. Identificación taxonómica de organismos que causan bioerosión, ichnotaxa e incrustación según Feige y Fürsich (1991).

1. Porcentaje de valvas fragmentadas.

Fragmento definido como $>$ de $10 \%$ ausente de la valva.

2. Porcentaje de valvas articuladas enteras.

3. Porcentaje de valvas desarticuladas enteras y abrasionadas. Abrasión definida como orillas redondeadas, pulimento y reducción de ornamento en el exterior de las valvas, identificables sin amplificación.

4. Porcentaje de valvas desarticuladas enteras y bioerosionadas. Bioerosión definida por la presencia de organismos que causan bioerosión en el interior o exterior de las valvas, reconocible con $10 x$ de amplificación . Categorias de bioerosión

a) algas endoliticas (taxonomía incierta)

b) esponjas cliónidas (Cliona spp., crean el ichnogénero Entobia)

c) poliquetos spiónidos (Polydora spp., crean los ichnogéneros Caulostrepsis, Maeandropolydora y Helicotaphrichnus)

d) bivalvos endolíticos (Gastrochaena

truncata y $G$. ovata, crean el ichnogénero Gastrochaenolites).
5. Porcentaje de valvas desarticuladas enteras e incrustadas. Incrustación definida por la presencia de organismos incrustadores en el interior o exterior de valvas enteras, visibles sin amplificación.

Categorias de incrustación

a) poliquetos serpúlidos (son comunes

Pomatostegus cf. polytrema, Serpula ef. concharum, Pomatoceras cf. triqueter y Spirorbis cf, variabilis)

b) gasterópodos vermétidos (Vermetus indentatus, Tripsycha tripsycha y Serpulorbis margaritaceus)

c) briozoarios

d) balanos

e) algas pardas

f) algas calcáreas

g) foraminíferos

h) bivalvos (ostras)

i) cnidarios (corales)

j) esponjas. suspension feeder, deposit feeder, algal grazer, scavenger, or predator. Species were also classified into the following life habit groups: infaunal, semi-infaunal, epifaunal-sessile or epifaunal-mobile. Trophic and life habit classification was made using Fürsich $e t$ al. (1991). Samples were also analyzed for the taphonomic variables summarized in table 2 . The raw data are available in Meldah! (1990), or on request.

Taphonomic variation in the samples was assessed using shells of two similar species of the robust venerid bivalve Chione: $C$. californiensis (Broderip, 1835) and C. fluctifraga (Sowerby, 1853). By limiting the taphonomic analysis to these bivalves, the differences in taphonomic susceptibility among shells of morphologically varying taxa were controlled. Both localizaron en un mapa base por triangulación. Hubo 49 sitios intermareales y 9 sitios submareales (hasta $10 \mathrm{~m}$ de profundidad debajo de la marea baja promedio). Las muestras se recolectaron excavando los $5 \mathrm{~cm}$ superiores del sedimento, que se cernieron utilizando una criba con malla de $6 \mathrm{~mm}$. Asi, se recolectaron conchas muertas hasta que se llenó una bolsa de muestras de 3.81 , cuando hubo suficientes conchas. Las muestras submareales se recolectaron mediante buceo libre y autónomo.

Las 58 muestras contuvieron un total de 12,690 individuos de 85 especies de moluscos identificables. Las especies se identificaron de acuerdo con Beckvar et al. (1987) y Keen (1971). Se clasificaron las especies en los siguientes grupos tróficos: suspensivoros, sedi- 
(a)

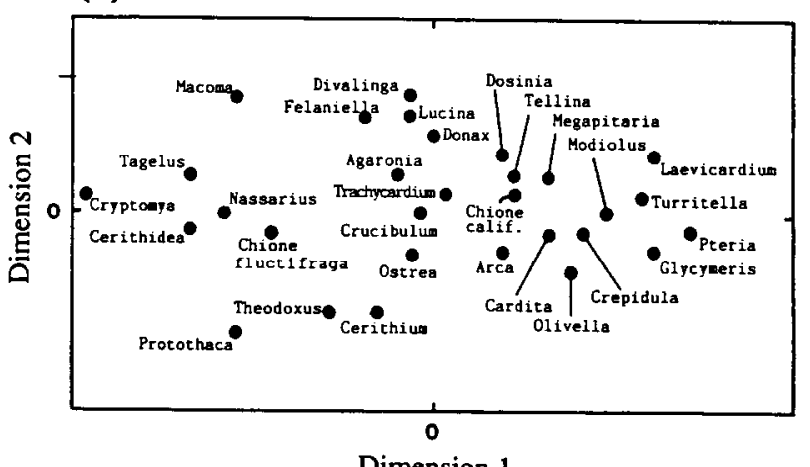

(b)

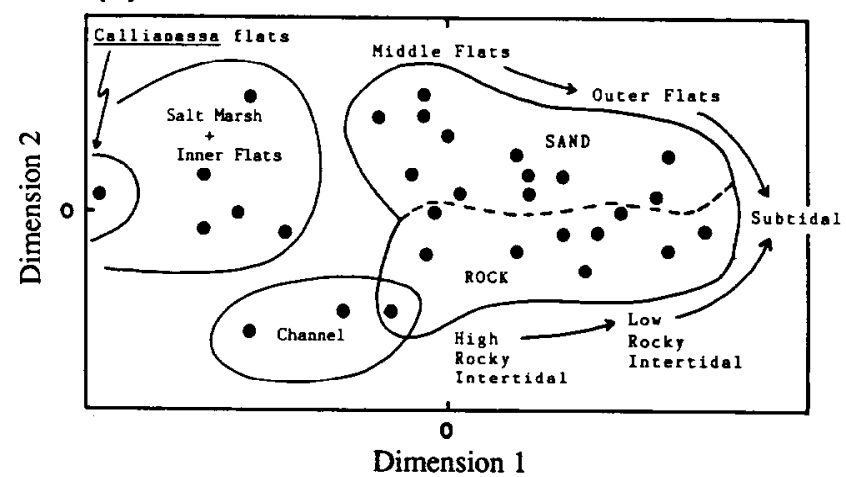

Figure 2. R-mode multidimensional scaling plots based on co-occurrence of 30 common molluscs in the samples (similarity measured by cosine $\theta$ ). (a) Distance on plot reflects degree of co-occurrence. Commonly co-occurring species plot close together, species that rarely co-occur plot far apart. (b) Same plot as (a) with environments and substrate preferences of the species indicated. The horizontal dimension of the plot reflects species distributions along an environmental gradient from upper intertidal to subtidal. Groupings in both dimensions demonstrate that substrate variation is an important control on species distributions.

Figura 2. Gráficas de escalamiento multidimensional de modo R, basadas en la coincidencia de treinta moluscos comunes en las muestras (semejanza medida por coseno $\theta$ ). (a) La distancia en la gráfica refleja el grado de coincidencia. Las especies que coinciden con frecuencia se grafican muy juntas, las especies que coinciden con poca frecuencia se grafican muy separadas. (b) La misma gráfica de (a) con los ambientes y preferencias de sustratos de las especies indicadas. La dimensión horizontal de la gráfica refleja la distribución de especies a lo largo de un gradiente ambiental intermarcal supcrior a submarcal. Las agrupaciones en ambas dimensiones demuestran que la variación del sustrato es un control importante para la distribución de las especies.

bivalves are shallow burrowers with similar shells, and are distinct enough to be recognizable even when highly altered. One or the other of these species occurs throughout the study area $(C$. californiensis is common in the lower intertidal and subtidal zones, and C. fluctifraga mentivoros, pacedores de algas, detritófagos, o depredatores. Las especies también se clasificaron por sus hábitos de vida, en los siguientes grupos: infáunico, seminfáunico, epifáunico sésil, o epifáunico móvil. La clasificación trófica y de hábitos de vida se hizo usando el texto 
in the upper intertidal and tidal channel). Supplemental collections of these species were made at sites where their abundance in original samples was low.

Q-mode cluster analysis (SPSSx; unweighted pair-group method) was used to delineate biofacies and taphofacies. This analysis identifies samples that are similar with regard to the variables being considered. Biofacies were delineated using variation in relative abundance of species, life habit groups and trophic groups among samples. Taphofacies were delineated using variation in taphonomic properties of Chione spp. among samples. R-mode nonmetric multidimensional scaling (SYSTAT) was used to identify molluscan species assemblages (groups of species that tend to occur together in samples). In all instances, similarity among each pair of samples (Q-mode) or among each pair of species (R-mode) was calculated using cosine $\theta$, an index that measures similarity in proportions of variables.

Cluster analysis and multidimensional scaling are useful exploratory techniques that identify patterns of similarity within multivariate data sets (Kruskal and Wish, 1978; Romesburg, 1984). There are no accepted methods for assigning levels of significance to the groups identified by these techniques.

\section{RESULTS AND DISCUSSION}

\section{Molluscan species assemblages}

$\mathrm{R}$-mode multivariate analysis is useful for identifying species assemblages (groups of species that tend to occur together). Figure 2 is an R-mode multidimensional scaling (MDS) plot of 30 species common to Bahía la Cholla. The distances between species on the MDS plot reflect their degree of co-occurrence in samples. Species that commonly co-occur plot close together, while species that rarely or never cooccur plot far apart.

As seen in Fig. 2b, the distribution of species reflects environment. The first dimension (horizontal axis) of the MDS plot represents changes in species composition occurring along de Fürsich et al. (1991). Las muestras también se analizaron según las variables tafonómicas que se resumen en la tabla 2 . Los datos sin procesar están disponibles en Meldahl (1990), o pueden solicitarse.

Se analizó la variación tafonómica en las muestras usando conchas de dos especies semejantes del bivalvo venérido robusto Chione: $C$. californiensis (Broderip, 1835) y C. fluctifraga (Sowerby, 1853). Limitando el análisis tafonómico a estos bivalvos, se controlaron susceptibilidades tafonómicas diferentes entre conchas morfológicamente variables. Ambos bivalvos son excavadores someros, con conchas semejantes, y son suficientemente distintos para ser reconocidos incluso cuando han sido muy alterados. Una u otra de estas especies está presente en el área de estudio $(C$. californiensis es común en las zonas intermareal baja y submareal, C. fluctifraga es común en la zona intermareal superior y el canal de marea). Se hicieron recolecciones suplementarias de estas especies en los sitios donde su abundancia fue baja en las muestras originales.

Se usó análisis de agrupamiento de modo $\mathrm{Q}$ (SPSSx; método de grupo par sin ponderar) para trazar las biofacies y tafofacies. El análisis de modo Q identifica muestras que son semejantes en cuanto a las variables consideradas. Las biofacies se trazaron siguiendo las variaciones en abundancia relativa de especies, grupos de hábitos de vida y grupos tróficos entre las muestras. Las tafofacies se trazaron usando las variaciones en las propiedades tafonómicas de Chione spp. entre las muestras. Se usó escalamiento multidimensional de modo $R$, no métrico (SYSTAT), para identificar conjuntos de especies de moluscos (grupos de especies que tienden a presentarse juntas en las muestras). En todos los casos, la semejanza entre cada par de muestras (modo Q) o entre cada par de especies (modo $\mathrm{R}$ ) se calculó con el coseno $\theta$, un índice que mide la semejanza en proporciones de variables.

El análisis de agrupamiento y el escalamiento multidimensional son técnicas exploratorias útiles para identificar patrones de semejanza dentro de conjuntos de datos multivariados (Kruskal y Wish, 1978; Romesburg, 
an environmental gradient from upper intertidal to lower intertidal to subtidal. The distribution of species in both dimensions of the plot primarily reflects variation in substratc. A distinct species assemblage characterizes the salt marsh and innermost tidal flats, environments dominated by fine organic-rich sediments. Other groupings on the plot generally subdivide species according to whether they occur primarily on hard substrates (shell gravel in the tidal channel, or rock in other areas) or on sand substrates.

\section{Biofacies based on molluscan species assemblages}

Biofacies are defined by recurring assemblages of species. Q-mode cluster analysis delineates biofacies by identifying samples that contain similar species assemblages. Figure 3 presents the Q-mode dendrogram and resulting biofacies map based on similarity in the relative abundance of molluscan species in the samples. The analysis delineates four major biofacies, corresponding to the following environments:

1. Salt marsh and innermost tidal flats (hexagons).

2. Inner. middle and outer tidal flats (circles).

3. Rocky intertidal zone, tidal channel and beach (squares).

4. Rocky subtidal zone (triangles).

Additionally, two samples that separate at the base of the dendrogram (Fig. 3) form a small yet distinct biofacies which represents the callianassid shrimp habitat on the inner tidal flats (open hexagons). Here, shell samples contain common Cryptomya californica, a commensal bivalve living within callianassid burrows.

The facies pattern in Fig. 3 primarily reflects variation in substrate. Each of the four major regions delineated on the facies map is characterized by a distinct substrate which supports a distinct assemblage of species. The salt marsh and innermost tidal flats are dominated by fine sand and silt. The dark color, reducing odor and cohesiveness of surface sediments at-
1984). No hay mćtodos accptados para asignar niveles de significación a los grupos identificados con estas técnicas.

\section{RESULTADOS Y DISCUSION}

\section{Conjuntos de especies de moluscos}

El análisis multivariado de modo $\mathrm{R}$ es útil para identificar conjuntos de especies, grupos de especies que tienden a presentarse juntas. La Fig. 2 es una gráfica escalada multidimensional de modo R (MDS) de las 30 especies comunes en bahía La Cholla. Las distancias entre especies en la gráfica MSD reflejan su grado de coincidencia dentro de las muestras. Comúnmente, las especies coincidentes están en la grafica muy juntas y las que nunca o casi nunca coinciden, muy separadas.

Como se ve en la Fig. 2, la distribución de especies refleja el ambiente. La primera dimensión (eje horizontal) de la gráfica representa cambios en la composición de especies que se presentan a lo largo de un gradiente ambiental de zona intermareal superior a inferior $y$ submareal. La distribución de especies en ambas dimensiones de la grálica refleja principalmente variaciones en el sustrato. Un conjunto particular de especies caracteriza la marisma y las planicies mareales más internas, ambientes dominados por sedimentos finos ricos en materia orgánica. Otros agrupamientos en la gráfica generalmente subdividen las especies según se encuentren principalmente en sustratos duros (grava de conchas en el canal de marea, o rocas en otras áreas) o en sustratos arenosos.

\section{Biofacies basadas en conjuntos de especies de moluscos}

Las biofacies se definen por los conjuntos recurrentes de especies. El análisis de agrupamientos de modo $Q$ traza las biofacies identificando las muestras que contienen conjuntos de especies similares. La Fig. 3 muestra el dendrograma de modo Q y el mapa de biofacies resultante, basados en la similitud de la abundancia relativa de las especies de moluscos de las 


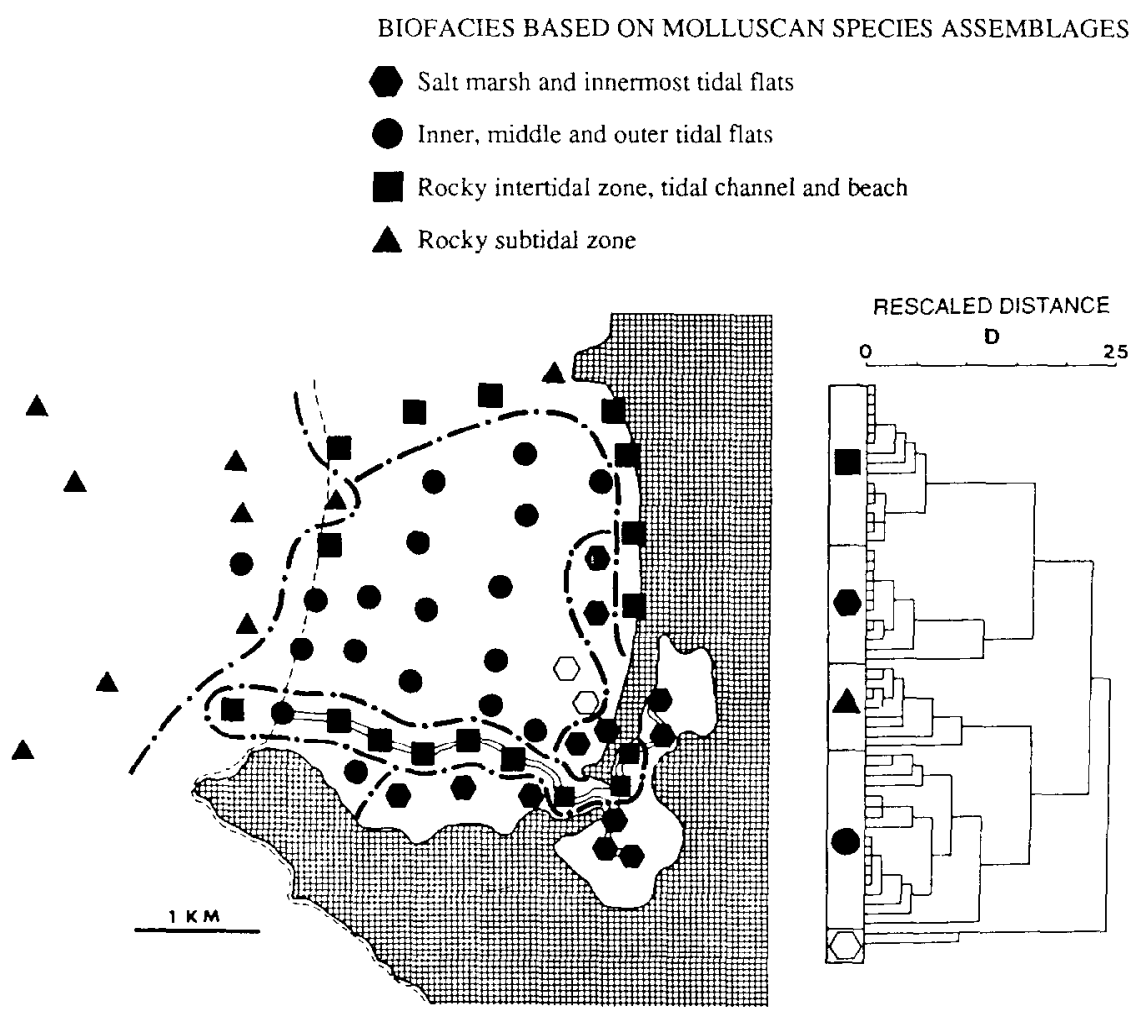

Figure 3. Q-mode cluster dendrogram and biofacies map based on similarity in molluscan species composition among samples (similarity measured by cosine $\theta$ ).

Figura 3. Dendrograma de agrupación de modo Q y mapa de biofacies, basados en la semejanza en composición de especies de moluscos entre las muestras (semejanza medida por coseno $\theta$ ).

test to high concentrations of organic matter. Common taxa in these environments are the deposit feeding gastropod Cerithidea mazatlanica (Carpenter, 1857), the scavenging gastropod Nassarius brunneostoma (Stearns, 1893), the deep infaunal suspension feeding bivalve Tagelus affinis (C.B. Adams, 1852), and the shallow infaunal suspension feeding bivalve $C$. fluctifraga. A relatively rare but diagnostic species of the salt marsh is the semi-infaunal byssate suspension feeding bivalve Mytella guyanensis (Lamark, 1819).

The inner, middle and outer tidal sand flats grade seaward from fine sand to sand ranging muestras. El análisis traza cuatro biofacies importantes, correspondientes a los siguientes ambientes:
1. Marisma y planicies mareales más internas (hexágonos).
2. Planicies mareales interna, media y externa (circulos).
3. Zona intermareal rocosa, canal de marea y playa (cuadrados).
4. Zona submareal rocosa (triángulos).

Adicionalmente, dos muestras que se separan en la base del dendrograma (Fig. 3) forman 
from fine to coarse. Shallow infaunal suspension feeding bivalves dominate these areas. Common taxa include C. californiensis, Lucina lampra (Dall, 1901), Parvilucina mazatlanica (Carpenter, 1855), Felaniella sericata (Reeve, 1850), Donax navicula (Hanley, 1845) and Trachycardium sp. Also common is the predalory gastropod Agaronia testacea (Lamark, 1811).

The tidal channel, rocky intertidal zone and beach are rather different environments, but have broadly similar molluscan assemblages. The similarity of species in the rocky intertidal zone and the tidal channel reflects the shared presence of hard substrates: dense shell gravel in the tidal channel, and low outcrops of Pleistocene coquina in the rocky intertidal zone. Common to both these habitats are the epifaunal algal grazing gastropods Cerithium stercusmuscarum (Valenciennes, 1833) and Theodoxus luteofasciatus (Miller, 1879), more common in the tidal channel, and the shallow burrowing bivalve $C$. californiensis, present in rocky intertidal death assemblages because it occurs commonly in shallow sand patches between rock outcrops. Common in the rocky intertidal zone, though usually absent in the tidal channel, are the epifaunal suspension feeding byssate bivalves Cardita affinis (Sowerby, 1833), Arca pacifica (Sowerby, 1833) and Modiolus capax (Conrad, 1837), and the epifaunal predatory gastropod Solenosteria macrospira (Berry, 1957). Common in the tidal channel, but absent from the rocky intertidal zone is the shallow infaunal bivalve Protothaca grata (Say, 1831). Beach samples occur in this biofacies because of transportation. Shelis originating in the rocky intertidal zone on the north side of the bay are transported southward along the beach by longshore drift.

The subtidal zone at Bahía la Cholla is characterized by mixed rock and sand. Rock substrates are formed by low outcrops of Pleistocene coquina, and these are separated by wide shallow patches of fine to coarse grained sand. This environment supports the highest diversity of species in the area. Common taxa on the rock substrates include the attached sessile epifaunal suspension feeding bivalves Pteria sterna (Gould, 1851), M. capax, C. affinis and A. paci- una pequeña pero diferente biofacies que representa el hábitat del camarón calianásido sobre las planicies mareales internas (hexágonos abiertos). Aquí, las muestras de conchas contienen comúnmente Cryptomya californica, un bivalvo comensal que vive con calianásidos excavadores.

El patrón de facies de la Fig. 3 refleja principalmente variación en el sustrato. Cada una de las cuatro regiones principales trazadas sobre el mapa de facies se caracteriza por un sustrato distinto, que soporta un conjunto diferente de especies. En la marisma y las planicies mareales más internas predomina arena fina y limo. El color obscuro, olor de reducción y cohesión de los sedimentos superficiales prueban las altas concentraciones de materia orgánica. En estos ambientes son comunes los gastrópodos como Cerithidea mazatlanica (Carpenter, 1857), el gastrópodo excavador Nassarius brunneostoma (Stearns, 1893), el bivalvo suspensívoro de la infauna profunda Tagelus affinis (C.B. Adams, 1852) y el bivalvo suspensívoro de la infauna somera $C$. fluctifraga. Una especie relativamente rara pero registrada en la marisma es el bivalvo suspensívoro bisado de la seminfauna somera Mytella guyanensis (Lamark, 1819).

Las planicies mareales intena, media y externa van graduándose de arena fina a gruesa, hacia el mar. En estas áreas predominan los bivalvos suspensivoros de la infauna somera. Están presentes comúnmente $C$. californiensis, Lucina lampra (Dall, 1901), Parvilucina mazatlanica (Carpenter, 1855), Felaniella sericata (Reeve, 1850), Donax navicula (Hanley, 1845) y Trachycardium sp. También es común el gastrópodo depredador Agaronia testacea (Lamark, 1811)

El canal de marea, la zona intermareal rocosa y la playa son ambientes bastante diferentes, pero tienen conjuntos de moluscos muy similares. La similitud de las especies de la zona intermareal rocosa y el canal de marea refleja la presencia compartida del sustrato duro: grava densa de conchas en el canal de marea y afloramientos bajos de coquina del pleistoceno en la zona intermareal rocosa. Común a estos dos hábitats son los gastrópodos epifáunicos pacedores de algas Cerithium stercusmuscarum 


\section{BIOFACIES BASED ON MOLLUSCAN TROPHIC GROUPS}
A Salt marsh and innermost tidal flats
Rocky intertidal zone, tidal channel, and beach
Inner, middle and outer tidal flats and rocky subtidal zone
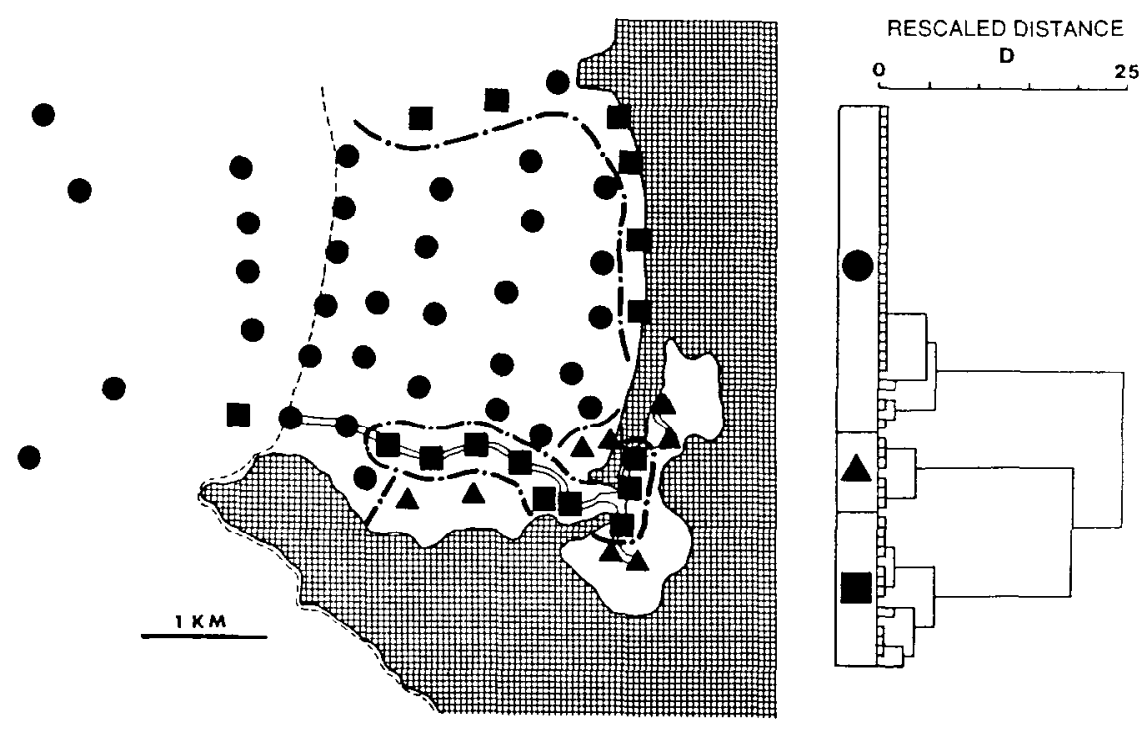

Figure 4. Q-mode cluster dendrogram and biofacies map based on similarity in molluscan trophic groups among samples (similarity measured by cosine $\theta$ ).

Figura 4. Dendrograma de agrupación de modo-Q y mapa de biofacies basados en semejanza en grupos tróficos moluscos entre muestras (semejanza medida por coseno $\theta$ ).

fica, and the attached sessile epifaunal suspension feeding gastropod Crepidula spp. Common taxa in sand patches between rock outcrops include the shallow infaunal suspension feeding bivalves $C$. californiensis, Megapitaria squalida (Sowerby, 1835), and Laevicardium elenese (Sowerby, 1840), the shallow infaunal deposit feeding bivalves Tellina spp. and Strigilla interupta (Moerch, 1860), and the semi-infaunal deposit feeding gastropod Turritella spp. Rarer but distinct taxa in this environment are the predatory gastropods $A$. testacea, Olivella dama (Wood, 1928), Oliva spp. and Polinices uber (Valenciennes, 1832).
(Valenciennes, 1833) y Theodoxus luteofasciatus (Miller, 1879), más comunes en el canal de marea, y el bivalvo excavador somero $C$. californiensis, presente en conjuntos muertos de la zona intermareal rocosa, porque se encuentra comúnmente en manchas de arena entre los afloramientos rocosos. Comunes en la zona intermareal rocosa, aunque usualmente ausentes en el canal de marea, son los bivalvos bisados suspensivoros de la epifauna Cardita affinis (Sowerby, 1833), Arca pacifica (Sowerby, 1833) y Modiolus capax (Conrad, 1837), así como el gastrópodo epifáunico depredador Solenosteria macrospira (Berry, 1957). El bivalvo 


\section{Biofacies based on trophic and life habit groups}

Variation in life habit groups and trophic groups in shallow marine invertebrate assemblages can be very helpful for detailed paleoenvironmental reconstruction (e.g., Walker and Bambach, 1974; Fürsich and Kirkland, 1986; Oschmann, 1988). Ecological attributes of Bahia la Cholla molluscan thanatocoenoces vary among environments, and thus can be used to identify biofacies.

Each mollusc species in shell samples was categorized according to its dominant trophic group (suspension feeder, deposit feeder, algal grazer, scavenger, or predator) and its dominant life habit (infaunal, semi-infaunal, epifaunalsessile or epifaunal-mobile). Q-mode cluster analyses were conducted based on the relative abundance of individuals of these trophic and life habit groups in the samples.

\section{Trophic groups}

The Q-mode dendrogram and resulting biofacies map, based on similarity in the trophic groups, are shown in Fig. 4. The analysis delineates three biofacies, corresponding to the following environments:

1. Salt marsh and innermost tidal flats (triangles).

2. Rocky intertidal zone, tidal channel, and beach (squares)

3. Inner, middle and outer tidal flats and rocky subtidal zone (circles).

The facies pattern in Fig. 4 is similar to the one based on species composition (Fig. 3), with the exception that the tidal flats are not differentiated from the rocky subtidal zone.

Though variation in trophic groups differentiates fewer facies than does variation in species composition, the facies that are distinguished appear to be controlled by substrate variation. The organic-rich sediments of the upper salt marsh and innermost tidal flats are dominated by deposit feeders. The shell and de la infauna somera Protothaca grata (Say, 1831) es común en el canal de mareas pero está ausente en la zona intermareal rocosa. Las muestras de playa se encuentran en estas biofacies debido a transporte. Las conchas originadas en la zona intermareal rocosa en el lado norte de la bahía son transportadas hacia el sur a lo largo de la playa por la corriente costera.

La zona submareal en bahía La Cholla se caracteriza por la mezcla de roca y arena. Los sustratos rocosos están formados por afloramientos bajos de coquina del preistoceno y están separados por manchas anchas y someras de arena fina a gruesa. Este ambiente sostiene la diversidad más alta de especies en el área Sobre los sustratos rocosos son comunes los bivalvos sésiles suspensívoros epifáunicos: Pteria sterna (Gould, 1851), M. capax, C. affinis, $A$ pacifica, y el gastrópodo sésil suspensívoro epifáunico Crepidula spp. En las manchas de arena entre los afloramientos rocosos son comunes los bivalvos suspensívoros de la infauna somera $C$. californiensis, Megapitaria squallida (Sowerby, 1835) Laevicardium elenese (Sowerby, 1840), los bivalvos sedimentivoros de la infauna somera: Tellina spp. y Strigilla interupta (Moerch, 1860), y el gastrópodo sedimentívoro seminfáunico Turritella spp. Más escasos pero claramente determinados en este ambiente se encuentran los gastrópodos depredadores A. testacea, Olivella dama (Wood, 1928), Oliva spp. y Polinices uber (Valenciennes, 1832).

\section{Biofacies basadas en grupos tróficos y de hábitos de vida}

La variación en grupos de hábitos de vida y grupos tróficos en los conjuntos de invertebrados marinos puede ser muy útil para la reconstrucción paleoambiental detallada (e.g., Walker y Bambach, 1974; Fürsich y Kirkland, 1986; Oschmann, 1988). Los atributos ecológicos de la tanatocenosis de moluscos de bahía La Cholla varían entre los ambientes y, por tanto, pueden usarse para identificar biofacies.

Cada especie de moluscos de las muestras de conchas se categorizó de acuerdo con su grupo trófico dominante (suspensívoros, sedi- 
rock substrates of the tidal channel and rocky intertidal are dominated by algal grazers. As in Fig. 3, the grouping of beach samples into this biofacies reflects southward longshore transportation of shells originating in the rocky intertidal region to the north. The sandy tidal flats and the mixed rock-sand subtidal zone are both dominated by suspension feeders. Because of the abundance of suspension feeders in ail these environments, the analysis of trophic groups does not differentiate them. Scavengers and predators apparently are not abundant enough to exert an effect on the facies pattern. However, predatory gastropods tend to be most common in the subtidal zone, while scavengers (particularly Nassarius spp.) are most common in the inner tidal flats.

\section{Life habit groups}

Shown in Fig. 5 are the Q-mode dendrogram and resulting biofacies map based on similarity in molluscan life habii groups. The dendrogram indicates strong separation into two major facies, corresponding to the following environments:

1. Salt marsh, innermost tidal flats, tidal channel, rocky intertidal and beach (squares).

2. Inner, middle and outer tidal sand flats and mixed rock-sand subtidal (circles).

The grouping of such a disparate set of environments as the salt marsh, inner tidal flats, tidal channel and rocky intertidal reflects the abundance in these habitats of mobile epifaunal gastropods, particularly Cerithidea spp. (salt marsh), Cerithium spp. (tidal channel and rocky intertidal) and Nassarius spp. (inner tidal flats). As in Figs. 3 and 4, the grouping of beach samples into this facies reflects southward longshore transportation of shells originating in the rocky intertidal region to the north. In contrast, the grouping of the middle and outer tidal sand flats with the mixed rock-sand subtidal zone reflects the dominance in these habitats of a diverse assortment of shallow infaunal bivalves. Although the abundance of epifauna increases in the subtidal zone due to the hard substrates, mentívoros, pacedores de algas, detritófagos, 0 depredadores) y su hábito dominante de vida (infáunico, seminfáunico, epifaúnico sésil, o epifáunico móvil). Los análisis de agrupamiento de modo Q se efectuaron con base en la abundancia relativa de los individuos de estos grupos tróficos y de hábitos de vida, en las muestras.

\section{Grupos trótícos}

El dendrograma de modo $Q$ y el mapa de biofacies resultante, basados en la similitud de los grupos tróficos se presenta en la Fig. 4. El análisis traza tres biofacies correspondientes a los siguientes ambientes:

1. Marisma y planicies mareales más internas (triángulos).

2. Zona intermareal rocosa, canal de marea y playa (cuadrados).

3. Planicies mareales interna, media y externa, y zona rocosa submareal (círculos).

El patrón de facies de la Fig. 4 es similar al basado en la composición de especies (Fig. 3), con la excepción de que las planicies mareales no están diferenciadas de la zona submareal rocosa.

Aunque la variación en los grupos tróficos diferencia menos facies que la variación en la composición de especies, las facies distinguidas parecen ser controladas por la variación de sustrato. Los sedimentos ricos en materia orgánica de la marisma superior y las planicies mareales más internas están dominados por organismos sedimentivoros. Los sustratos de concha y roca del canal de marea y la zona intermareal rocosa están dominados por pacedores de algas. Como se ve en la Fig. 3, el agrupamiento de muestras de playa en estas biofacies refleja transporte hacia el sur de las conchas originadas en la región intermareal rocosa del norte. Las planicies mareales arenosas y la región submareal mezclada de arena y roca están dominadas por organismos suspensivoros. Debido a la abundancia de suspensívoros en todos estos ambientes, el análisis de grupos tróficos no los distingue. Los detritófagos y los depredadores no son suficien- 
infauna are still abundant in the sand patches between rock oulcrops. Thus, the sandy intertidal and rocky subtidal environments are not differentiated by the cluster analysis.

Variation in life habit groups (Fig. 5) differentiates fewer facies than does variation in species composition (Fig. 3) or variation in trophic groups (Fig. 4). The analysis essentially differentiates epifauna-dominated environments from infauna-dominated environments. These environments encompass a variety of substrate types. There appear to be no useful generalizations to be made about the environmental factors controlling this facies pattern.

\section{Taphofacies}

Taphofacies, based on grouping fossil assemblages that share taphonomic features, can be valuable indicators of ancient environments and sedimentary processes, and are receiving increasing attention in paleoenvironmental reconstruction (e.g., Speyer and Brett, 1988; Norris 1986; Miller et al., 1988; Brandt, 1989). Taphonomic studies in modern sedimentary environments are essential for determining the environmental significance of ancient taphofacies. Holocene taphofacies studies have been conducted in environments as diverse as reefrelated carbonate (Parsons, 1989), siliciclastic intertidal to shallow subtidal (Meldahl and Flessa, 1990), hurricane-influenced coastal inlet (Davies et al., 1989), and inner continental shelf (Staff and Powell, 1990). These studies have provided valuable insights into the origin and environmental significance of taphonomic features.

Taphonomic variation in shells of the similar venerid bivalves $C$. californiensis and $C$. fluctifraga was assessed. The taphonomic variables are summarized in table 2 . All the variables were subjected to Q-mode cluster analysis to reveal taphonomically similar groups of samples, or taphofacies. Figure 6 shows the Q-mode cluster dendrogram and resulting facies map. The analysis identifies three major taphofacies, corresponding to the following sets of environments: temente abundantes para ejercer un efecto sobre el patrón de facies. Sin embargo, los gastrópodos depredadores tienden a ser más comunes en la zona intermareal, mientras los detritófagos (particularmente Nassarius spp.) son más comunes en las planicies mareales internas.

Grupos de hábitos de vida

El dendrograma de modo Q y el mapa de biofacies resultante, con base en la similitud de hábitos de vida de los moluscos, se muestra en la Fig. 5. El dendrograma indica una fuerte separación entre las dos facies principales, que corresponden a los siguientes ambientes:

1. Marisma, planicies mareales más internas, canal de marea, zona intermareal rocosa y playa (cuadrados).

2. Planicies mareales arenosas interna, media $y$ superior, y zona submareal mezclada de arena y roca (círculos).

El agrupamiento de un conjunto tan desigual de ambientes, como marisma, planicies mareales internas, canal de marea y zona intermareal rocosa, refleja la abundancia en estos hábitats de gastrópodos móviles epifáunicos, en particular de Cerithidea spp. (marisma), Cerithium spp. (canal de marea y zona intermareal rocosa) y Nassarius spp. (planicies mareales internas). Como se ve en las Figs. 3 y 4 , el agrupamiento de muestras de playa en estas biofacies refleja el transporte hacia el sur, a lo largo de la playa, de las conchas originadas en la región intermareal rocosa del norte. En contraste, el agrupamiento de las planicies mareales arenosas media y externa con la zona submareal mezclada de arena y roca refleja el predominio en estos hábitats de un surtido diverso de bivalvos de la infauna somera. Aunque la abundancia de epifauna aumenta en la zona submareal, debido a los sustratos duros, la infauna también es abundante en las manchas de arena entre los afloramientos rocosos. Por ello, los ambientes intermareal arenoso y submareal rocoso no se diferenciaron en el análisis de agrupamientos.

La variación en los grupos de hábitos de vida (Fig. 5) diferencia menos facies que la va- 

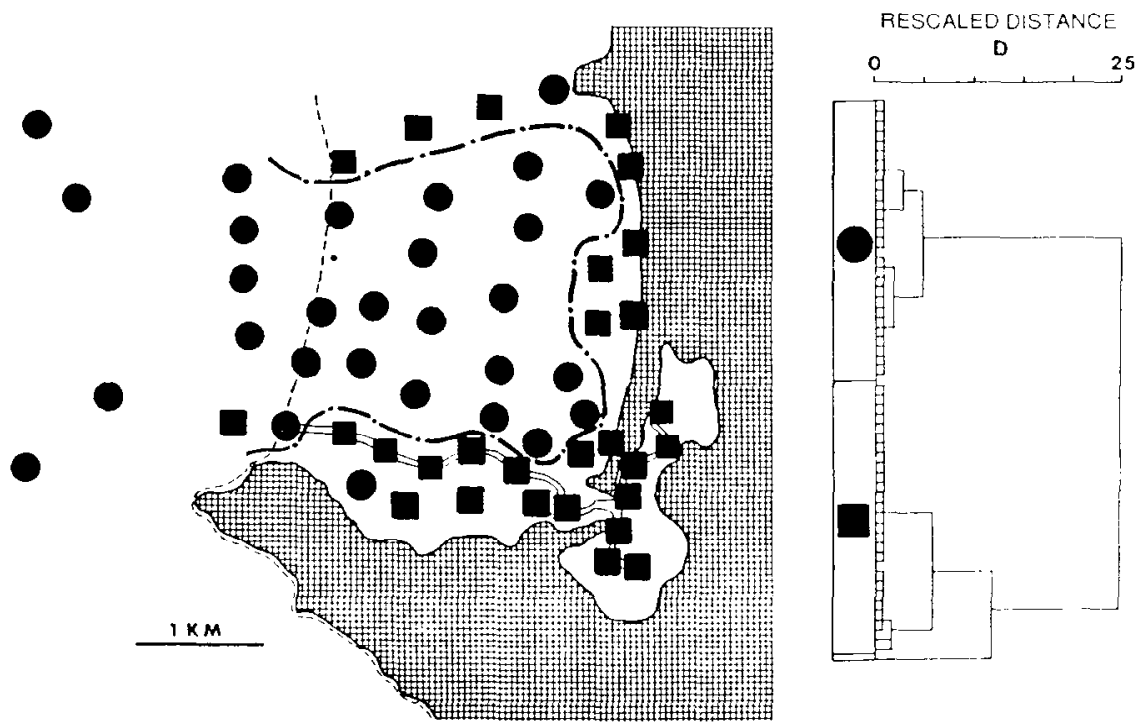

Figure 5. Q-mode cluster dendrogram and biofacies map based on similarity in molluscan life habit groups among samples (similarity measured by cosine $\theta$ ).

Figura 5. Dendrograma de agrupación de modo Q y mapa de biofacies, basados en la semejanza en grupos de hábitos de vida de moluscos entre muestras (semejanza medida por $\operatorname{coseno} \theta$ ).

1. Outer tidal flats, rocky intertidal zone, and rocky subtidal zone (circles).

2. Tidal channel (triangles).

3. Salt marsh, inner tidal flats, middle tidal flats and beach (squares).

These sets of environments are taphonomically distinct. The outer tidal flats, rocky intertidal zone, and rocky subtidal zone are characterized by generally high levels of taphonomic alteration, particularly abrasion, bioerosion by clionid sponges and endolithic bivalves, and encrustation by bryozoans.

The tidal channel is also characterized by high levels of taphonomic alteration, particularly abrasion, fragmentation, bioerosion by algae, and encrustation by serpulid polychaetes. riación en la composición de especies (Fig. 3) o la variación en grupos tróficos (Fig. 4). El análisis distingue esencialmente los ambientes donde predomina la epifauna de aquéllos donde predomina la infauna. Estos ambientes comprenden una variedad de tipos de sustrato. Al parecer no hay generalizaciones útiles que se puedan hacer sobre los factores ambientales que controlan este patrón de facies.

\section{Tafofacies}

Las tafofacies, basadas en el agrupamiento de los conjuntos fósiles que comparten características tafonómicas, pueden ser indicadores importantes de los ambientes antiguos y de los procesos sedimentarios, y están recibiendo cada 
In contrast, the salt marsh, inner and middle tidal flats exhibit generally low levels of taphonomic alteration. Abrasion, bioerosion and encrustation are usually low (although algal bioerosion is often high in the salt marsh), and shells tend to be in good condition. Beach samples are grouped with this "low alteration" taphofacies because, though abrasion is always very high on the beach, beach shells exhibit low levels of all other forms of taphonomic alteration. Thus, the weight of the other taphonomic variables causes the beach samples to join other samples having low levels of alteration. During longshore transport, beach shells are beavily abraded, and taphonomic features previously acquired (especially encrustation and shallow bioerosion) may be obliterated by abrasion.

The facies pattern in Fig. 6 primarily reflects variation in submergence time and current energy. The duration of submergence by the tide increases seaward across the tidal flats. Lower intertidal and shallow subtidal areas are submerged during the peak periods of flood and cbb current flows, and thus experience more powerful physical reworking than upper intertidal areas, which are emergent during peak flow periods. Shells in lower intertidal and subtidal areas are abraded by the high tidal current velocities, and are commonly highly bioeroded and encrusted due to prolonged or continuous submergence.

The tidal channel experiences the strongest current flows of any environment, since it serves as the main drainage for the salt marsh, and handles confined flows during much of the tidal cycle. The channel is continuously submerged, even at the lowest tides. As a result, channel shells exhibit the highest levels of taphonomic alteration. The tidal channel forms a facies that is taphonomically distinct from the outer flat and subtidal areas because of differences in the dominant types of bioerosion and encrustation. Shells from the outer flats and subtidal zones are commonly bioeroded by clionid sponges, endolithic bivalves and algae, and encrusted by bryozoans, whereas it is common for shells in the tidal channel to be highly bioeroded by endolithic algae, and encrusted by serpulid polychaetes. vez más atención en la reconstrucción paleoambiental (e.g., Speyer y Brett, 1988; Norris, 1986; Miller et al,, 1988; Brandt, 1989). Los estudios tafonómicos en ambientes sedimentarios modernos son esenciales para determinar el significado de las tafofacies antiguas. Se han efectuado estudios sobre las tafofacies del holoceno en ambientes tan diversos como carbonatos arrecifales (Parsons, 1989), sustratos silicoclásticos de zonas intermareal a submareal somera (Meldahl y Flessa, 1990), ensenada costera afectada por huracanes (Davies et al., 1989) y plataforma continental interna (Staff y Powell, 1990). Estos estudios han proporcionado percepciones valiosas acerca del origen y la significación ambiental de las características tafonómicas.

Se estudió la variación tafonómica en conchas de los bivalvos venéridos semejantes $C$. californiensis y C. fluctifraga. Las variables tafonómicas se resumen en la tabla 2 . Todas estas variables se sometieron a un análisis de agrupamiento de modo $Q$ para revelar grupos de muestras tafonómicamente semejantes, o tafofacies. La Fig. 6 muestra el dendrograma de agrupamiento de modo $Q$ y el mapa de facies resultante. El análisis identifica tres tafofacies mayores, correspondientes a los siguientes conjuntos de ambientes:

1. Planicies mareales externas, y zonas rocosas intermareal y submareal (círculos).

2. Canal de marea (triángulos).

3. Marisma, planicies mareales internas y medias, y playa (cuadros).

Estos conjuntos de ambientes son tafonómicamente diferentes. I.as planicies mareales externas y las zonas rocosas intermareal y submareal se caracterizan por niveles generalmente altos de alteración tafonómica, particularmente abrasión y bioerosión causada por esponjas cliónidas y bivalvos endolíticos, así como incrustación por briozoarios.

El canal de marea se caracteriza también por niveles altos de alteración tafonómica, en particular, abrasión, fragmentación, bioerosión por algas e incrustación por poliquetos serpúlidos. 
In contrast, the salt marsh, inner and middle tidal flats are subject to relatively short periods of submergence. These environments experience relatively low levels of tidal current energy, due to short submergence time and because currents move relatively slowly on either side of the high tide peak of the tidal cycle. Shells in these environments are thus altered slowly. This is confirmed by shell radiocarbon dates. Flessa et al. (1993) obtained a calendar age of 1,886 $(+223 /-196)$ y.b.p. for a shell collected from the surface of the inner tidal flats that exhibited very little taphonomic alteration.

\section{Effects of shell transportation on facies patterns}

If shells commonly undergo significant lateral transportation after death, biofacies and taphofacies patterns derived from shell death assemblages will be inaccurate. Thus, it is important to assess the potential importance of lateral shell transportation at Bahía la Cholla.

Several studies in intertidal environments suggest that post-mortem physical transportation of shells is generally low (Warme et al., 1976; Peterson, 1976). Likewise, Fürsich and Flessa (1987) demonstrated that lateral transportation of dead shells at Bahia la Cholla is minimal. They compared the distribution of live individuals to the distribution of dead remains, and found that, in spite of the strong tidal currents, the distribution of dead shells closely mimics the distribution of live individuals across the tidal flats.

A demonstration of the extent of physical transportation on the Bahía la Cholla tidal flats is shown in Fig. 7. Modiolus capax is a byssate epifaunal bivalve with a moderately robust shell, that lives attached to hard substrates in low intertidal and shallow subtidal areas. Figure 7 shows how the relative abundance of $M$. $c a$ pax declines rapidly with distance from its rock substrate habitat. While $M$. capax valves can occur in samples collected more than $2,500 \mathrm{~m}$ away from rock substrates, indicating that some valves can be transported great distances, allochthonous valves in such distant samples are rare.
En contraste, la marisma y las planicies mareales internas y medias presentan niveles generalmente bajos de alteración tafonómica. Usualmente, la abrasión, bioerosión e incrustación son bajas (aunque la bioerosión por algas es con frecuencia alta en la marisma) y las conchas tienden a estar en buenas condiciones. Las muestras de playa se agrupan con esta tafofacies de "baja alteración" porque, a pesar de que la abrasión siempre es muy alta en la playa, las conchas de playa muestran niveles bajos de todas las demás formas de alteración tafonómica. Así, el peso de las demás variables tafonómicas causa que las muestras de playa se junten con otras muestras de niveles bajos de alteración. Durante el transporte a lo largo de la costa, las conchas de playa se desgastan mucho y los rasgos tafonómicos previamente adquiridos, especialmente la incrustación y la bioerosion somera, pueden ser borrados por la abrasión.

El patrón de facies de la Fig. 6 refleja particularmente la variación en el tiempo de sumersión y la energía de corriente. La duración de sumersión por la marea se incrementa hacia el mar através de las planicies mareales. Las áreas intermareales más baja y somera se sumergen durante los periodos máximos de inundación y bajamar de los flujos de corriente, y por eso experimentan un retrabajo físico más fuerte que las áreas intermareales superiores, que emergen durante los periodos de máximo flujo. Las conchas en las áreas intermareal baja y submareal son desgastadas por las altas velocidades de corriente de marea y están comúnmente muy bioerosionadas e incrustadas, debido a la sumersión prolongada o continua.

El canal de marea recibe flujos de corrientes más fuertes que cualquier otro ambiente, ya que sirve como drenaje principal de la marisma y conduce flujos confinados durante gran parte del ciclo mareal. El canal está sumergido continuamente, incluso durante las mareas más bajas. Como resultado, las conchas del canal tienen los niveles más altos de alteración tafonómica. El canal de marea forma una facies que es tafonómicamente distinta de las áreas de la planicie externa y submareal, debido a las diferencias en los tipos dominantes de bioerosión e incrustación. Las conchas de las planicies 


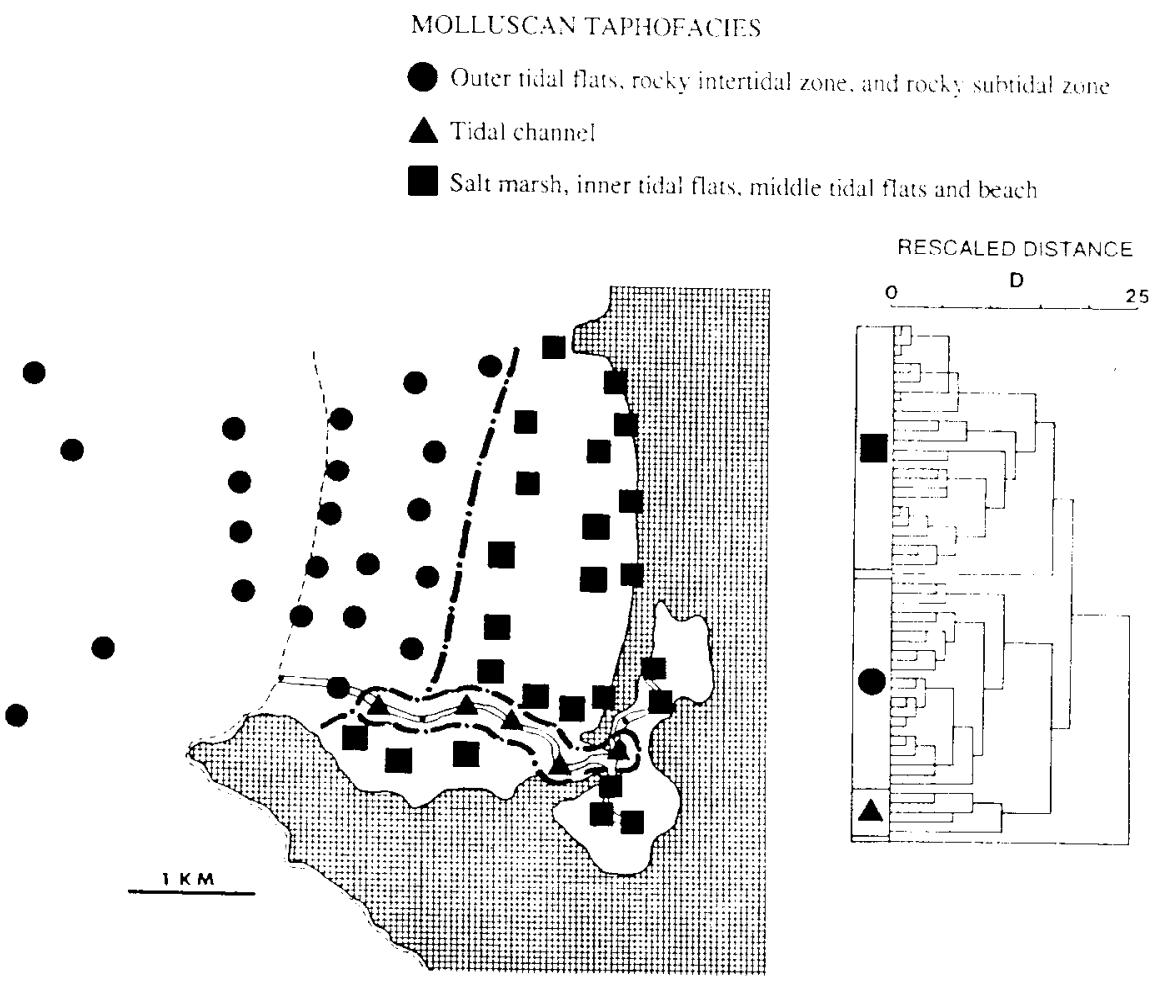

Figure 6. Q-mode cluster dendrogram and taphofacies map based on similarity in molluscan taphonomy among samples (similarity measured by $\operatorname{cosine} \theta$ ).

Figura 6. Dendrograma de agrupación de modo $Q$ y mapa de tafofacies basados en la semejanza en tafonomía de moluscos entre muestras (semejanza medida por $\operatorname{coseno} \theta$ ).

In summary, post-mortem transportation of shells is unlikely to obscure ecological and taphonomic patterns at Bahia la Cholla. Significant lateral transportation of large numbers of shells appears to be restricted to southward longshore movernent of shells along the beach.

\section{CONCLUSIONS}

Molluscan shell assemblages at Bahía la Cholla record the responses of both living communities and dead shells to their environment. Variations in species composition, trophic and life habit groups define biofacies that primarily reflect variations in substrate. The organic rich fine sediments of the salt marsh and innermost tidal flats are dominated by epifaunal deposit externas y las zonas submareales con frecuencia están bioerosionadas por esponjas cliónidas, bivalvos y algas endolíticas, e incrustadas por briozoarios, mientras que las conchas del canal de marea están con frecuencia altamente bioerosionadas por algas endolíticas e incrustadas por poliquetos serpúlidos.

En contraste, la marisma y las planicies mareales internas y medias están sujetas a periodos relativamente cortos de sumersión. Estos ambientes experimentan niveles relativamente bajos de energia de corriente de marea, debido tanto al corto tiempo de sumersión como al hecho de que las corrientes se mueven relativamente despacio en cualquiera de los extremos del punto máximo de la marea alta. Como consecuencia, las conchas en estos ambientes se al- 
feeders and deep infaunal suspension feeders. The inner, middle and outer tidal flats contain fine to coarse grained sand, and are dominated by shallow infaunal suspension feeders. The tidal channel and rocky intertidal zone contain hard substrates, shell gravel and Pleistocene coquina outcrops, respectively, and are dominated by epifaunal algal grazers. The subtidal zone contains alternating rock and sand substrates, and is dominated by a diverse community of sessile epifaunal suspension feeders and shallow infaunal suspension feeders.

Variation in the taphonomy of Chione spp. valves defines taphofacies. Taphofacies are distributed differently than biofacies, and appear to be governed by variation in submergence time and current energy. The outer tidal flats, rocky intertidal zone, and rocky subtidal zone together form a taphofacies characterized by high levels of abrasion, bioerosion by clionid sponges and endolithic bivalves, and encrustation by bryozoans. These environments experience prolonged or continuous tidal submergence and high tidal current velocities. The tidal channel forms a taphofacies characterized by high levels of abrasion, bioerosion by algae, and encrustation by serpulid polychaetes. This environment experiences continuous submergence and the strongest tidal current velocities. Together, the salt marsh, inner and middle tidal flats are characterized by low levels of taphonomic alteration. These environments experience relatively short periods of submergence and low tidal current velocities.

Major transportation of shells at Bahía la Cholla is limited to longshore movement along the beach, and probably does not affect ecologic and taphonomic facies patterns elsewhere in the area.

This study demonstrates the potential advantages of incorporating taphonomic data into paleoenvironmental analysis. Assuming the Bahia la Cholla depositional system were preserved in the stratigraphic record, the variation in substrate would probably be readily discernible from lithologic data. In contrast, variation in submergence time and current energy would not necessarily be reflected clearly by lithologic data, but could be revealed by taphonomic data. teran lentamente. Esto se confirma con las fechas de radiocarbón en las conchas. Flessa et al. (1993) obtuvieron una edad calendárica de 1,886 años $(+223 /-196)$ para una concha tomada de la superficie de las planicies mareales internas, la cual mostró muy poca alteración tafonómica.

\section{Efectos del transporte de conchas sobre los patrones de facies}

Si las conchas con frecuencia experimentan transporte lateral significativo después de la muerte, los patrones de biofacies y tafofacies derivados de conjuntos muertos de conchas no pueden ser precisos. Por tanto, es importante analizar la importancia potencial del transporte lateral de conchas en bahia La Cholla.

Varios estudios de ambientes intermareales sugieren que el transporte fisico post mortem de las conchas es generalmente bajo (Warme et al., 1976; Peterson, 1976). Asimismo, Fürsich y Flessa (1987) demostraron que el transporte lateral de conchas muertas en bahía La Cholla es mínimo. Estos autores compararon la distribución de individuos vivos con la distribución de restos muertos y descubrieron que, a pesar de las fuertes corrientes mareales, la distribución de conchas muertas sigue estrechamente la distribución de individuos vivos a través de las planicies mareales.

Una demostración del grado de trasporte fisico en las planicies mareales de bahía La Cholla se presenta en la Fig. 7. Modiolus capax es un bivalvo bisado epifáunico con una concha moderadamente robusta, el cual vive adherido a sustratos duros en las áreas intermareales baja y somera. La Fig. 7 muestra cómo la abundancia relativa de $M$. capax disminuye rápidamente con el distanciamiento de su hábitat de sustrato rocoso. Mientras que valvas de $M$. capax pueden encontrarse en muestras tomadas a más de $2,500 \mathrm{~m}$ de sustratos rocosos, lo que indica que algunas valvas pueden ser transportadas grandes distancias, las valvas alóctonas son poco comunes en muestras tan lcjanas .

En resumen, es poco probable que el transporte post mortem de conchas obscurezca los patrones ecológicos y tafonómicos en bahia La 


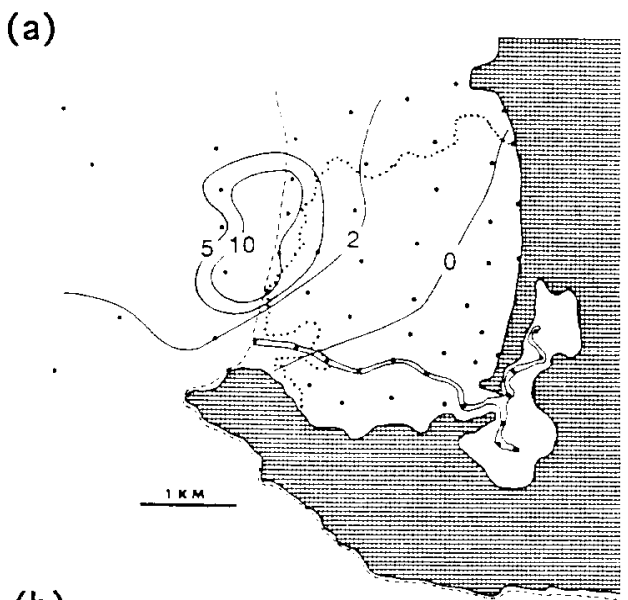

(b)

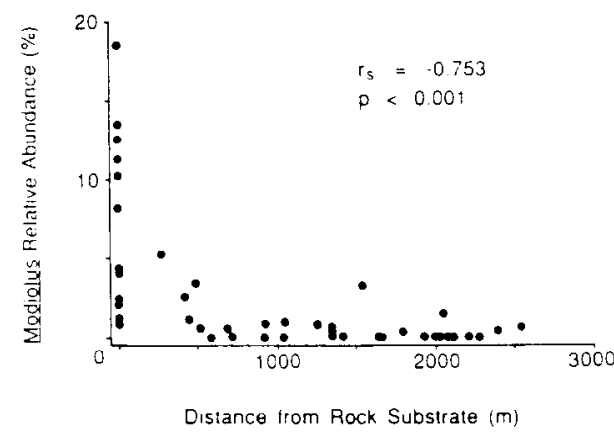

Figure 7. Transportation of Modiolus capax valves. (a) Contour map of the percentage of relative abundance of $M$. capax in samples. Dotted line indicates transition from rock substrate (north and west of line) to sand substrate (south and east of line). Modiolus capax lives only on rock substrates, so its occurrence in sandy areas reflects transportation. (b) Plot of $M$. capax percentage of relative abundance versus distance from nearest rock substrate. Although $M$. capax valves can be transported more than $2,500 \mathrm{~m}$ from its rock habitat, they are typically rare (less than $2 \%$ relative abundance in samples). (The p-value indicates correlation is highly significant; $r_{s}=$ Spearman rank correlation coefficient.)

Figura 7. Transporte de valvos Modiolus capax. (a) Mapa de contorno del porcentaje de abundancia relativa de $M$. capax en las muestras. La linea punteada indica la transición de sustrato rocoso (al norte y al oeste de la línea) a sustrato arenoso (al sur y este de la línea). $M$. capax vive solamente en sustratos rocosos, asi que su presencia en áreas arenosas refleja transporte. (b) Gráfica del porcentaje de abundancia relativa de $M$. capax contra distancia al sustrato rocoso más cercano. Aunque valvos de $M$. capax pueden ser transportados a más de $2,500 \mathrm{~m}$ de su hábitat rocoso, típicamente son poco frecuentes (menos de $2 \%$ de abundancia relativa en muestras). (El valor de $\mathrm{p}$ indica que la correlación es altamente significativa; $r_{s}=$ coeficiente de correlación de rango Spearman.) 
Further studies of the environmental significance of taphonomic features in modern sedimentary environments will pave the way to more robust interpretations of such features in the stratigraphic record.

\section{ACKNOWLEDGMENTS}

This work was completed as part of a Ph.D. dissertation at the University of Arizona. I thank Karl Flessa for his generous advice and support throughout this study; and Miguel Téllez for his useful comments on the manuscript. Thanks to Andrew Cohen, Alan Cutler, Ellinor Michel and Kelly West for help in the field. Thanks to Karl Flessa, Franz Fürsich, Alan Cutler, Martin Aberhan and Andreas Feige for their insights into Bahía la Cholla. Many thanks to the residents of Puerto Peñasco, Sonora. Support was provided by grants from the Geological Society of America, the Paleontological Society, the American Association of Petroleum Geologists, and Sigma Xi.

\section{REFERENCES}

Aberhan, M. and Fürsich, F.T. (1991). Paleoecology and paleoenvironments of the Pleistocene deposits of Bahía la Choya (Gulf of California, Sonora, Mexico). In: F.T. Fürsich and K.W. Flessa (eds.), Ecology, Taphonomy and Paleoecology of Recent and Pleistocene Molluscan Faunas of Bahía la Choya, Northern Gulf of California. Zitteliana, 18: 135-164.

Beckvar, N., Norris, R.D. and Suter, S. (1987). Keys to the shells of Bahía la Choya, Sonora, Mexico. In: K.W. Flessa (ed.), Paleoecology and Taphonomy of Recent to Pleistocene Intertidal Deposits, Gulf of California. Paleontological Society Special Publication, 2: 62-103.

Brandt, D.S. (1989). Taphonomic grades as a classification for fossiliferous assemblages and implications for paleoecology. Palaios, 4: 303-309.

Brett, C.E. and Baird, G.C. (1986). Comparative taphonomy: $\Lambda$ key to paleoenviron-
Cholla. La transportación lateral significativa de gran número de conchas parece restringirse al movimiento de las conchas hacia el sur, a to largo de la playa.

\section{CONCLUSIONES}

Los conjuntos de conchas de moluscos de bahía La Cholla registran las respuestas al ambiente, tanto de comunidades vivas como de conchas muertas. Las variaciones en la composición de especies, grupos tróficos y grupos de hábitos de vida definen biofacies que reflejan principalmente variaciones en el sustrato. Los sedimentos finos y ricos en materia orgánica de la marisma y de las planicies mareales más internas están dominados por epifauna sedimentivora e infauna profunda suspensívora. Las planicies mareales interna, media y externa contienen arena de grano fino a grueso, y están dominadas por infauna poco profunda suspensivora. El canal de marea y la zona intermareal rocosa contienen sustratos duros, grava de conchas y afloramientos de coquina del preistoceno, respectivamente, y están dominados por pacedores de algas epifáunicos. La zona submareal contiene sustratos alternados de roca y arena, y está dominada por una comunidad diversa de epifauna sésil suspensivora e infauna somera suspensívora.

La variación en la tafonomía de valvas de Chione spp. define las tafofacies. I as tafofacies están distribuidas de manera distinta que las biofacies, $y$ parecen estar gobernadas por variaciones en tiempo de sumersión y energía de corriente. Las planicies mareales externas, y las zonas rocosas intermareal y submareal forman en conjunto una tafofacies caracterizada por niveles altos de abrasión, bioerosión por esponjas cliónidas y bivalvos endoliticos, e incrustación por briozoarios. Estos ambientes experimentan sumersión mareal prolongada o continua y altas velocidades de corriente mareal. El canal de marea forma una tafofacies caracterizada por niveles altos de abrasión, bioerosión por algas e incrustación por poliquetos serpúlidos. Este ambiente experimenta sumersión continua y las velocidades de corriente de marea más fuertes. La marisma y las plani- 
mental interpretation based on fossil preservation. Palaios, 1: 207-227.

Cutler, A.H. (1991). Processes of hardpart breakdown and models of stratigraphic disorder in shallow marine environments. Ph.D. dissertation, University of Arizona, Tucson, Arizona.

Davies, D.J., Powell, E.N. and Stanton, R.J., Jr. (1989). Taphonomic signature as a function of environmental process: shells and shell beds in a hurricane-influenced inlet on the Texas coast. Palaeogeography, Palaeoclimatology, Palaeoecology, 72(2): 317-356.

Davies, D.J., Staff, (i.M., Callender, W.K. and Powell, E.N. (1990). Description of a quantitative approach to taphonomy and taphofacies analysis: all dead things are not created equal. In: W. Miller (ed.), Paleocommunity Temporal Dynamics: The Long-term Development of Multispecies Assemblages. Paleontological Society Special Publication, 5: 328-350.

Feige, A. and Fürsich, F.T. (1991). Taphonomy of the Recent molluses of Bahía la Choya. In: F.T. Fürsich and K.W. Flessa (eds.). Ecology, Taphonomy and Paleoecology of Recent and Pleistocene Molluscan Faunas of Bahia la Choya, Northern Gulf of California. Zitteliana, 18: 89-134.

Flessa, K.W., editor (1987). Paleoecology and Taphonomy of Recent to Pleistocene Intertidal Deposits, Gulf of California. Paleontological Society Special Publication, 2: $237 \mathrm{pp}$.

Flessa, K.W.. Cutler. A.H. and Meldahl, K.H. (1993). Time and taphonomy: quantitative estimates of time-averaging and stratigraphic disorder in a shallow marine habitat. Paleobiology, 19: 266-286.

Fürsich, F.T. and Flessa, K.W. (1987). Taphonomy of tidal tlat molluses in the northern Gulf of California: palcocnvironmental analysis despite the perils of preservation. Palaios. 2: 543-559.

Fürsich. F.T and Flessa. K.W.. editors (1991). Ecology, Taphonomy and Paleoecology of Recent and Pleistocene Molluscan Faunas of Bahía la Choya, Northern Gulf of California. Zitteliana. 18: 180pp. cies mareales internas y medias, en conjunto, se caracterizan por niveles bajos de alteración tafonómica. Estos ambientes experimentan periodos relativamente cortos de sumersión y bajas velocidades de corriente de marea.

El mayor transporte de conchas en bahía La Cholla se limita a movimientos a lo largo de la playa, y probablemente no afecta los patrones de facies ecológicos y tafonómicos en otras partes del área.

Este estudio demuestra las ventajas potenciales de incorporar datos tafonómicos al análisis paleoambiental. Asume que el sistema de depósito de bahía La Cholla ha sido preservado en el registro estratigráfico. Es probable que la variación en el sustrato se pudiera discernir fácilmente de la información litológica. En contraste, las variaciones en tiempo de sumersión y en energía de corriente no es seguro que fueran claramente reflejadas por los datos litológicos, pero podrían ser reveladas por datos tafonómicos. Estudios adicionales sobre el significado ambiental de las características tafonómicas en los ambientes sedimentarios modernos abrirán el camino a interpretaciones más sólidas de tales rasgos en el registro estratigráfico.

\section{AGRADECIMIENTOS}

Este trabajo se completó como parte de una disertación doctoral en la Universidad de Arizona. Se agradece a Karl Flessa su generosa asesoria y apoyo, así como a Miguel Téllez los útiles comentarios sobre el manuscrito. Se agradece igualmente la colaboración en el campo brindada por Andrew Cohen, Alan Cutler, Ellinor Michel y Kelly West. Gracias a Karl Flessa, Franz Fürsich, Alan Cutler, Martin Aberhan y Andreas Feige por sus percepciones sobre la bahía La Cholla. Muchas gracias a los residentes de Puerto Peñasco, Sonora. Se contó con becas de la Geological Society of America, $\mathrm{Pa}$ leontological Society. American Association of Petroleum Geologists y Sigma Xi.

Traducido al español por Michelle McCunney y Olivia Gómez Mora. 
Fürsich, F.T. and Kirkland, J.I. (1986). Biostratinomy and paleoecology of a Cretaceous lagoon. Palaios, 1: 543-560.

Fürsich, F.T., Flcssa, K.W., Abcrhan, M., Feige, A. and Schodlbauer, S. (1991). Sedimentary habitats and molluscan faunas of Bahia la Choya (Gulf of California, Sonora, Mexico). In: F.T. Fürsich and K.W. Flessa (eds.), Ecology, Taphonomy and Paleoecology of Recent and Pleistocene Molluscan Faunas of Bahía la Choya, Northern Gulf of California. Zitteliana, 18: 5-51.

Greenstein, B.J. (1991). An intergrated study of echinoid taphonomy: Predictions for the fossil record of four echinoid families. Palaios, 6: 519-540.

Kcon, A.M. (1971). Sea Shells of Tropical West America, 2nd edition. Stanford University Press, Stanford, 1064 pp.

Kidwell, S.M. (1991). The stratigraphy of shell concentrations. In: P.A. Allison and D.E.G. Briggs (eds.), Taphonomy: Releasing the Data Locked in the Fossil Record. Plenum Press, N.Y., pp. 212-290.

Kidwell, S.M. and Bosence, D.W.J. (1991). Taphonomy and time-averaging of marine shelly faunas. In: P.A. Allison and D.E.G. Briggs (eds.), Taphonomy: Releasing the Data Locked in the Fossil Record. Plenum Press, N.Y., pp. 115-209.

Kruskal, J.B. and Wish, M. (1978). Multidimensional Scaling, Sage University Paper Series on Quantitative Applications in the Social Sciences 11. Sage Publications, Beverly Hills, 93 pp.

Meldahl, K.H. (1987). Sedimentologic and taphonomic implications of biogenic stratification. Palaios, 2: 350-358.

Meldahl, K.H. (1990). Paleoenvironmental and stratigraphic implications of taphonomic processes: case studies from Recent and Pleistocene shallow marine environments. $\mathrm{Ph} . \mathrm{D}$. dissertation, University of Arizona, Tucson, Arizona, $440 \mathrm{pp}$.

Meldahl, K.H. (1993). Geographic gradients in the formation of shell concentrations: PlioPleistocene marine deposits, Gulf of California. Palaeogeography, Palaeoclimatology, Palaeoecology, 101: 1-25.
Meldahl, K.H. and Flessa, K.W. (1990). Taphonomic pathways and comparative biofacies and taphofacies in a Recent intertidal/shallow shelf environment. Lethaia, 23: 43-60.

Miller, K.B., Brett, C.E. and Parsons, K.M. (1988). The paleoecologic significance of storm-generated disturbance within a Middle Devonian muddy epeiric sea. Palaios, 3: 35-52.

Norris, R.D. (1986). Taphonomic gradients in shelf fossil assemblages: Pliocene Purisima Formation, California. Palaios, 1: 256-270.

Oschmann, W. (1988). Upper Kimmeridgian and Portlandian marine benthic associations from southern England and northern France. Facies, 18: 49-82.

Ortlieb, L. (1991). Quaternary shorelines along the northeastern Gulf of California: geochronological data and neotectonic implications. Geological Society of America, Special Paper, 254: 95-120.

Parsons, K.M. (1989). Taphonomy as an indicator of environment: Smuggler's Cove, St. Croix, U.S.V.I. In: D.K. Hubbard (ed.), Terrestrial and Marine Ecology of St. Croix, U.S. Virgin Islands, Special Publication 8. West Indies I,aboratory, St. Croix, Virgin Islands, pp. 135-143.

Parsons, K.M. and Brett, C.E. (1991). Taphonomic processes and biases in modern marine environments: an actualistic perspective on fossil assemblage preservation. In: S.K. Donovan (ed.), The Processes of Fossilization. Columbia University Press, N.Y., pp. 22-65.

Peterson, C.H. (1976). Relative abundances of living and dead molluscs in two California lagoons. Lethaia, 9: 137-148.

Romesburg, H.C. (1984). Cluster Analysis for Researchers. Life-Time Learning Publications, Belmont, California, $334 \mathrm{pp}$.

Speyer, S.E. and Brett, C.E. (1988). Taphofacies models for epeiric sea environments: Middle Paleozoic examples. Palaeogeography, Palaeoclimatology, Palaeoecology, 63: 225-262.

Staff, G.M. and Powell, E.N. (1990). Taphonomic signature and the imprint of tapho- 
nomic history: discriminating between taphofacies of the inner continental shelf and a microtidal inlet. In: W. Miller (ed.), Paleocommunity Temporal Dynamics, Paleontological Society Special Publication 5: 370-390.

Stearley, R.F. and Ekdale, A.A. (1989). Modern marine bioerosion by macroinvertebrates, northern Gulf of California. Palaios 4: 453-467.

Thompson, D.A. (1993). 1993 Tide Calender for the Northern Gulf of California. University of Arizona Press, Tucson.
Walker, R.K. and Bambach, R.K. (1974). Feeding by benthic invertebrates: classification and terminology for paleoecological analysis. Lethaia, 7: 67-78.

Warme, J.E., Ekdale, A.A., Ekdale, S.F. and Peterson, C.H. (1976). Raw material of the fossil record. In: R.W. Scott and R.R. West (eds.), Structure and Classification of Paleocommunities. Dowden, Hutchinson and Ross, Stroudsburg, Pennsylvania, pp. 143-169. 